\title{
Continuous 300,000-year fossil record: changes in the ornithofauna of Biśnik Cave, Poland
}

\author{
Teresa Tomek, Zbigniew M. Bocheński, Paweł Socha, \\ and Krzysztof Stefaniak
}

\begin{abstract}
Biśnik Cave is situated in a limestone rock about $50 \mathrm{~km}$ northeast of Kraków, southern Poland. Its importance stems from the fact that it is one of the few sites in Europe, and the only one in Poland, with 300,000-year-long sequence of uninterrupted sediments, that cover the time span from before the Saalian to the Holocene. The excavations yielded about 200,000 animal bones and more than 4,000 stone, bone and antler artifacts. Bird remains from Biśnik Cave consist of nearly 1,600 skeletal fragments of at least 96 taxa that represent a minimum of 285 individuals. The majority of the remains belong to Galliformes; relatively numerous are also Corvidae, Falconiformes, Anseriformes and the genus Turdus. The remains include one extinct taxon (Falco tinnunculus atavus) and four species new for the Polish fossil avifauna (Aquila heliaca, Pinicola enucleator, Loxia pytyopsittacus and Carduelis flammea). Avian remains indicate a mosaic of various habitats in the surroundings of Biśnik Cave. Some kind of mature forest or at least sparsely growing trees, as well as water bodies, marshes, wet meadows, steppe and tundra habitats must have been present during the entire time of sedimentation. It is postulated that the Kraków-Częstochowa Upland was a local refugium for the forest fauna during the Saalian and Vistulian glaciations.
\end{abstract}

Teresa Tomek . Institute of Systematics and Evolution of Animals, Polish Academy of Sciences, Slawkowska 17, 31-016 Krakow, Poland. tomek@isez.pan.krakow.pl

Zbigniew M. Bocheński. Institute of Systematics and Evolution of Animals, Polish Academy of Sciences, Slawkowska 17, 31-016 Krakow, Poland. (correspondance author) bochenski@isez.pan.krakow.pl Paweł Socha. Department of Palaeozoology, Zoological Institute, University of Wroclaw, Sienkiewicza 21, 50-335 Wrocław, Poland. sochap@biol.uni.wroc.pl

Krzysztof Stefaniak. Department of Palaeozoology, Zoological Institute, University of Wroclaw, Sienkiewicza 21, 50-335 Wrocław, Poland. stefanik@biol.uni.wroc.pl

Keywords: fossil birds, Pleistocene, palaeoenvironment, palaeoclimate 


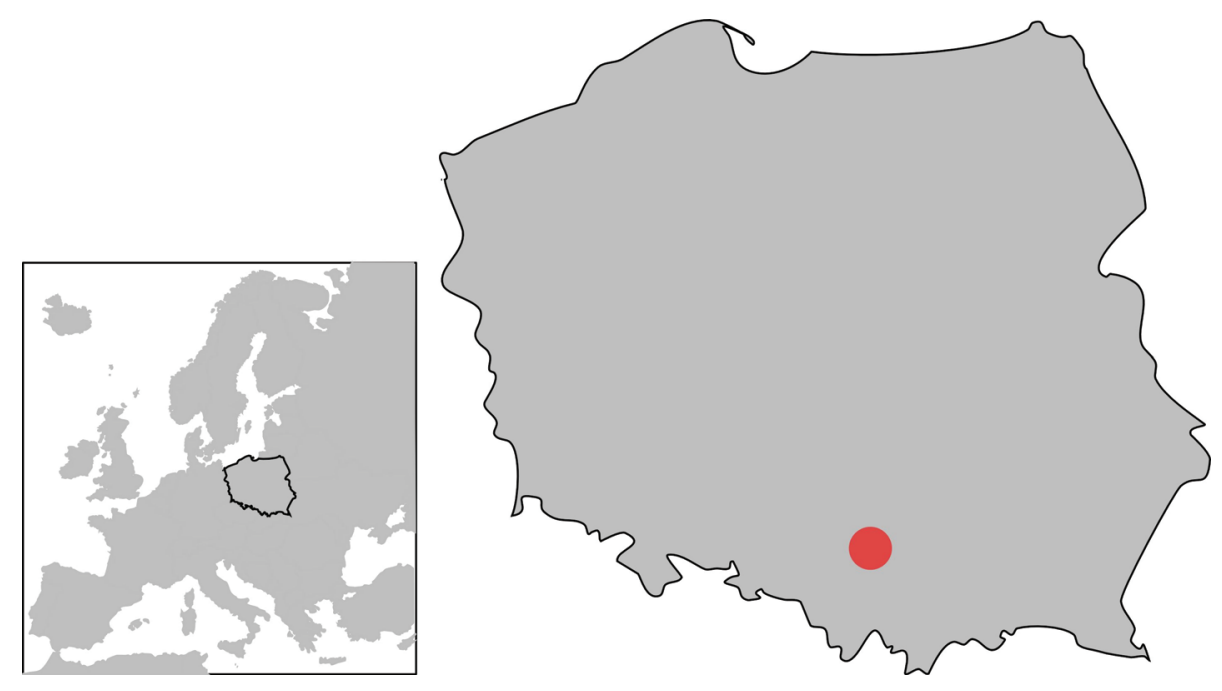

FIGURE 1. Location of Biśnik Cave in southern Poland.

\section{INTRODUCTION}

Biśnik Cave is situated in a limestone rock, $405 \mathrm{~m}$ above sea level, ca $50 \mathrm{~km}$ northeast of Kraków, in the central part of the KrakówCzęstochowa Upland $\left(50^{\circ} 23^{\prime} \mathrm{N}\right.$; $\left.19^{\circ} 40^{\prime} \mathrm{E}\right)$ (Figure 1). The cave has several entrances located in the western slope of the valley Dolina Wodąca; it forms a large cave system that includes Biśnik and Psia caves (Kowalski, 1951; Cyrek, 2002; MirosławGrabowska, 2002).

Biśnik Cave is very unique not only in Poland but in Europe as well. It is the only site in Poland and, in fact, one of very few in Europe, where the stratigraphy of sediments has been preserved intact from before the Odra Glacial period to the Holocene (Cyrek, 2002, 2003; Madeyska and Cyrek, 2002; Mirosław-Grabowska, 2002; Cyrek et al., 2010). Moreover, a sequence of at least 10 mid-Palaeolithic cultural levels makes Biśnik Cave one of the most important middle-Palaeolithic sites in central Europe (Cyrek et al., 2010). Chronology of the site is based on the thermoluminescence (TL) and the Uranium-Thorium (U/Th) dating methods. Altogether more than 40 datings were performed on the sediments, bone and flint artifacts (Cyrek et al., 2010) (Table 1).

The exploration of the sediments of Biśnik Cave that began in 1991 under the supervision of K. Cyrek covered $260 \mathrm{~m}^{2}$, reached the depth of $150-850 \mathrm{~cm}$ from the ground surface and yielded exceptionally rich archaeological and palaeontological materials - about 200,000 bones (Wiszniowska et al., 2001, 2002; Cyrek et al., 2010; Van Asperen and Stefaniak, 2011), and more than 4000 stone, bone and antler artefacts were recovered
(Mirosław-Grabowska, 2002; Cyrek et al., 2010). Published results of studies on Biśnik Cave include its geology, stratigraphy and archaeology (Mirosław-Grabowska, 2002; Cyrek, 2003; Cyrek et al., 2009), and faunal analyses (Wiszniowska et al., 2001, 2002, 2004; Socha, 2009; Stefaniak and Marciszak, 2009; Cyrek et al., 2010; Marciszak and Stefaniak, 2010; Van Asperen and Stefaniak, 2011). So far the avifauna of Biśnik Cave has not been studied in detail. Some of the published reports that included birds (Wiszniowska et al., 2001, 2002, 2004; Krewsun, 2003) relied on superficial analyses and unfortunately suffered from some identification mistakes. Others (Stefaniak et al., 2009) included only partial data. The present study is the first and most complete analysis of all the bird remains of Biśnik Cave.

\section{MATERIAL AND METHODS}

In many cases the bones were identified to species or genus level, with the help of the following comparative skeletal collections: Institute of Systematics and Evolution of Animals, Polish Academy of Sciences (ISEA); National Museum of Natural History, Bulgarian Academy of Scienses (NMNHS); Staatsammlung für Anthropologie und Paläoanatomie, München, Germany (SAP); Zoologisk Museum, Copenhagen, Denmark (ZMUC); Zoological Museum of the University of Oulu, Finland (ZMUO); and the authors' experience (Bocheński and Tomek, 1995, 2009; Tomek and Bocheński, 2000, 2009; Jenner et al., 2001; Bocheński, 2008). Numerous small fragments and such elements as foot phalanges or vertebrae 
TABLE 1. Results of absolute dating methods for various layers of Biśnik Cave (Cyrek et al., 2010; Van Asperen and Stefaniak, 2011). EU=Early Uptake model; LU=Linear Uptake model (Pike and Hedges, 2001).

\begin{tabular}{|c|c|c|c|c|c|}
\hline MIS & Layer & Climatostratigraphy & $\begin{array}{c}\text { Fauna } \\
\text { complexes }\end{array}$ & Method & Date (ka BP) \\
\hline 1 & 1 & Holocene & I & & \\
\hline \multirow[t]{4}{*}{2} & \multirow[t]{4}{*}{2} & \multirow[t]{4}{*}{ Upper Plenivistulian } & \multirow[t]{4}{*}{ II } & U-series on bone & 37-93 (EUmin-LUmax) \\
\hline & & & & \multirow[t]{3}{*}{ TL on sediment } & $25 \pm 3$ \\
\hline & & & & & $26 \pm 3$ \\
\hline & & & & & $29 \pm 4$ \\
\hline \multirow[t]{3}{*}{3} & \multirow[t]{3}{*}{$3-4$} & \multirow[t]{3}{*}{ Middle Plenivistulian } & \multirow[t]{3}{*}{ III } & \multirow[t]{2}{*}{ TL on flint } & $54 \pm 10$ \\
\hline & & & & & $58 \pm 11$ \\
\hline & & & & U-series on bone & 32-79 (EUmin-LUmax) \\
\hline \multirow[t]{4}{*}{4} & $5-6$ & \multirow[t]{4}{*}{ Lower Plenivistulian } & \multirow[t]{2}{*}{ IV } & TL on sediment & $67 \pm 15$ \\
\hline & 7 & & & U-series on bone & 94-96 (EUmin-LUmax) \\
\hline & \multirow[t]{2}{*}{8} & & \multirow[t]{15}{*}{$\mathrm{V}$} & U-series on bone & 106-270 (EUmin-LUmax) \\
\hline & & & & TL on sediment & $120 \pm 22$ \\
\hline \multirow[t]{6}{*}{$5 a$} & \multirow[t]{6}{*}{9} & \multirow[t]{17}{*}{ Early Vistula Glacial } & & U-series on bone & 11-30 (EUmin-LUmax) \\
\hline & & & & \multirow[t]{2}{*}{ TL on sediment } & $96 \pm 27$ \\
\hline & & & & & $127 \pm 24$ \\
\hline & & & & \multirow[t]{3}{*}{ TL on flint } & $81 \pm 17$ \\
\hline & & & & & $86 \pm 14$ \\
\hline & & & & & $94 \pm 17$ \\
\hline \multirow[t]{3}{*}{$5 b$} & \multirow[t]{3}{*}{10} & & & U-series on bone & 48-106 (EUmin-LUmax) \\
\hline & & & & TL on sediment & $101 \pm 27$ \\
\hline & & & & TL on flint & $97 \pm 17$ \\
\hline \multirow[t]{2}{*}{$5 c$} & \multirow[t]{2}{*}{11} & & & U-series on bone & 60-153 (EUmin-LUmax) \\
\hline & & & & TL on flint & $108 \pm 21$ \\
\hline \multirow[t]{4}{*}{$5 d$} & 12 & & & U-series on bone & 31-66 (EUmin-LUmax) \\
\hline & & & & TL on sediment & $142 \pm 27$ \\
\hline & & & VI & TL on flint & $122 \pm 22$ \\
\hline & & & & & $135 \pm 23$ \\
\hline & 13 & & & U-series on bone & 63-143 (EUmin-LUmax) \\
\hline $5 e$ & & & & TL on flint & $126 \pm 25$ \\
\hline 6 & 14 & Warta Glacial & VII & U-series on bone & 56-126 (EUmin-LUmax) \\
\hline & & & & TL on flint & $81 \pm 17$ \\
\hline & & & & & $139 \pm 33$ \\
\hline & & & & & $195 \pm 35$ \\
\hline & & & & & $224 \pm 49$ \\
\hline 7 & 15 & Lubawa Interglacial & VIII & U-series on bone & 216-930 (EUmin-LUmax) \\
\hline & & & & TL on flint & $195 \pm 35$ \\
\hline & 18 & Odra Glacial & IX & U-series on bone & 116-346 (EUmin-LUmax) \\
\hline 8 & & & & TL on sediment & $230 \pm 60$ \\
\hline & & & & TL on flint & $230 \pm 51$ \\
\hline & & & & & $279 \pm 97$ \\
\hline & 19 & & & U-series on bone & 125-346 (EUmin-LUmax) \\
\hline
\end{tabular}


were excluded from the study and remained unidentified.

During the first few years of excavations bones were retrieved from the sediment by hand; later the sediments were wet-sieved. About onefourth of the remains come from well-defined stratigraphic levels; the other bones are assignable to larger stratigraphic units that include two or more levels or come from samples in which stratigraphy was not precisely determined. For further analyses we followed the stratigraphic division into nine "fauna complexes" distinguished on the basis of the mammalian fauna recovered (Cyrek et al., 2010, table 3) and, consequently, we included in the analyses only the remains that could be assigned to one of the complexes. The correlation between particular layers, their climatostratigraphy and faunal complexes is explained in Table 1.

For the purpose of palaeoenvironmental analyses, we assigned each taxon to one of five general groups of habitats, distinguished on the basis of the breeding requirements (Tomek and Bocheński, 2005; Nadachowski et al., 2009): "amphibious," "forest," "ecotone," "open habitats," and "tundra." The "amphibious" habitats included all types of freshwater lakes, ponds, rivers, marshes and even wet meadows. The "forest" habitats comprised all types of forests and parklands. The "ecotone" included a transition area between forest and grassland, the "open" habitats comprised treeless and dry meadows, steppes and rocky mountains, and the category "tundra" was restricted to open habitats of higher latitudes. The grouping of some species in general habitat types was not always easy because their breeding habitat may fall into two groups. In such cases it was done authoritatively in a manner similar to previous studies (Tomek and Bocheński, 2005; Bocheński and Tomek, 2009) to ensure compatibility of subsequent comparisons.

The results are presented as the number of identified specimens (NISP) and the minimum number of individuals ( $\mathrm{MNI}$ ), which was calculated for each taxon within particular layer of sediment (Lyman, 2008).

\section{RESULTS}

Bird remains from Biśnik Cave consist of nearly 1,600 skeletal fragments of at least 96 taxa that represent at least 285 individuals (Table 2-see end of article). Approximately half of the remains belong to Galliformes (NISP=772), relatively numerous are also Corvidae (NISP=176), Falconiformes (NISP=109), followed by Anseriformes
(NISP=95) and the genus Turdus (NISP=83). Remains of other taxa are less numerous. Only three species, all of them galliforms (Lagopus lagopus, Tetrao tetrix and Gallus gallus), are represented by more than 100 bones or their fragments, and the remains of only 14 other species show NISP greater than 10 . The remaining taxa are represented by 10 or fewer specimens only.

Only a little more than a half of all the remains (807) were ascribed to particular fauna complexes, whereas the other bones (775) were retrieved from mixed sediments (Table 2). The most abundant in avian remains was fauna complex I attributed to the Holocene (NISP=206), complexes VII (Warta Glacial) and III (Middle Plenivistulian) were the least numerous, whereas each of the other fauna complexes yielded several dozen bones.

Remains of only two species (Lagopus lagopus and Tetrao tetrix) were found in all the fauna complexes distinguished (Table 2). One species (Corvus monedula) was absent from one fauna complex, and two other species (Falco tinnunculus and Lagopus muta) were present in all but two fauna complexes. The remaining taxa showed more accidental distribution.

Four species are new for the Polish fossil avifauna. They include the Eastern Imperial Eagle Aquila heliaca (distal tibiotarsus, layer $2 / 4=$ fauna complex II/III, Middle-Upper Plenivistulian); the Pine Grosbeak Pinicola enucleator (complete carpometacarpus, unknown stratigraphy); the Parrot Crossbill Loxia pytyopsittacus (mandible, layer 15 = fauna complex VIII, Lubawa Interglacial; beak, unknown stratigraphy); and the Common Redpoll Carduelis flammea (complete humerus, layer $2=$ fauna complex II, Upper Plenivistulian).

Falco tinnunculus atavus Jánossy, 1972 is the only extinct taxon found in the material. It is represented by two specimens (a complete ulna and a distal tarsometatarsus) of unknown stratigraphy (Figure 2).

Not fully ossified remains of subadult and/or immature birds consist of 125 bones of at least 21 taxa (Table 3). Two-thirds of the not fully ossified remains were retrieved from mixed sediments, and only 50 fragments were assigned to particular layers - they represent all but one of the fauna complexes.

All fauna complexes included taxa that represented four types of habitat: amphibious, forest, ecotone and tundra (Figure 3, Table 2). Taxa breeding in "open" habitats were not recorded in two fauna complexes (VII and III). The distribution of taxa in particular fauna complexes was uneven. 


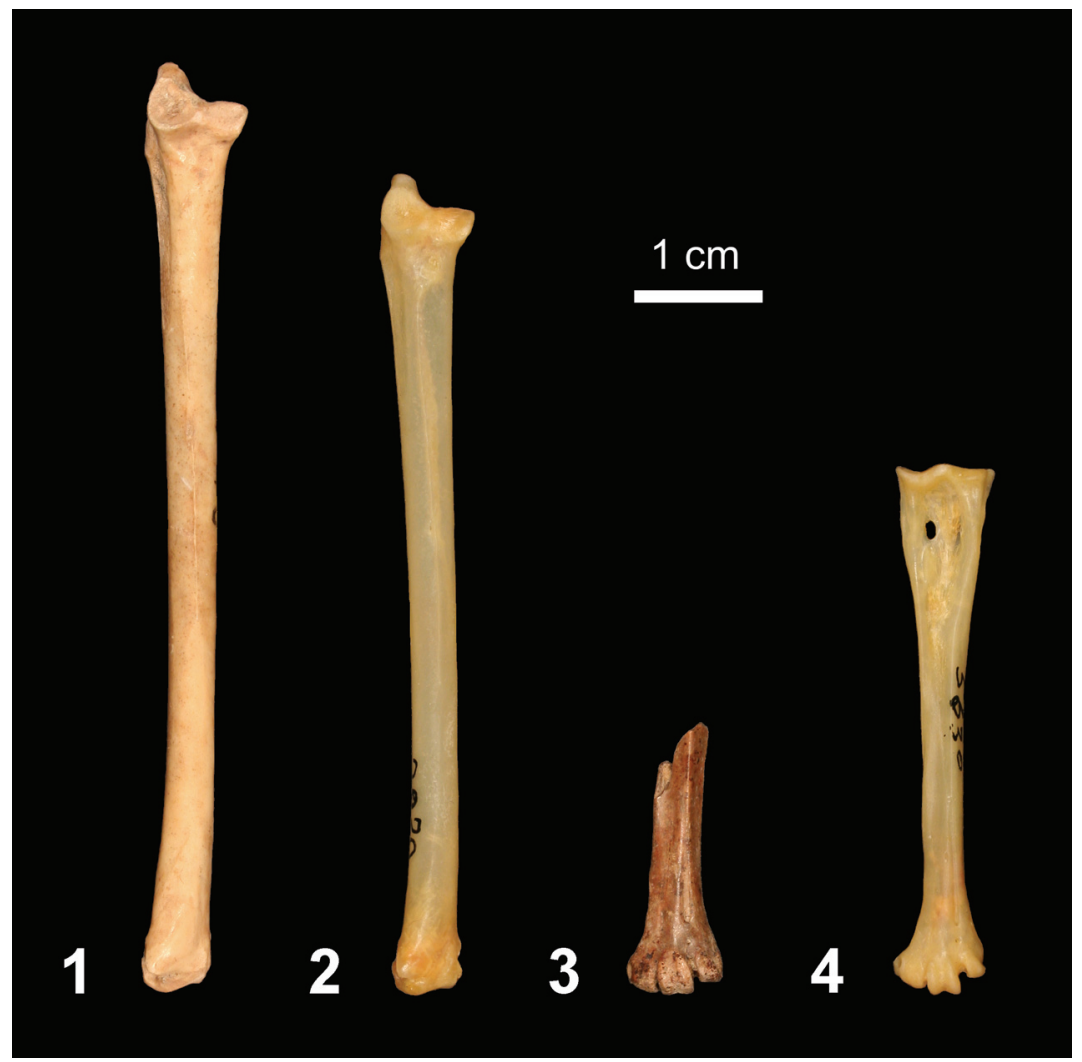

FIGURE 2. Left ulna in cranial view and left tarsometatarsus in dorsal view. Falco tinnunculus atavus (1,3) and modern female of Falco tinnunculus $(2,4)$. The fossil specimen is much larger and more robust than a large modern female.

The share of birds connected with water, and various humid habitats fluctuated but generally increased from the Odra Glacial (fauna complex IX) to the Upper Plenivistulian (fauna complex II). Forest species showed the most stable share in all fauna complexes. Complex VI (Eemian) had relatively little tundra species, whereas complex III (Middle Plenivistulian) showed the opposite trend, with tundra species being the most numerous.

\section{COMMENTS, DISCUSSION AND CONCLUSIONS}

\section{New Taxa for the Polish Fossil Avifauna}

The Eastern Imperial Eagle (Aquila heliaca) Nowadays it is found mainly within Mediterranean and steppe zones from southeastern Europe to central Asia (Cramp and Simmons, 1980). Most populations are migratory and winter in northeastern Africa, and southern and eastern Asia. In Poland it is observed sporadically (Tomiałojć and Stawarczyk, 2003). It is known since the Middle Pleistocene of Austria and Azerbaijan, and from several Late Pleistocene localities of Austria, Swit- zerland, Hungary, Romania and Georgia (Tyrberg, 1998a, 1998b). Biśnik Cave is the northern-most fossil site of the species.

The Pine Grosbeak (Pinicola enucleator) Nowadays it is found in subarctic Fennoscandia, Siberia, Alaska and North America. It is a very rare vagrant to Poland and temperate Europe (Cramp and Perrins, 1994; Tomiałojć and Stawarczyk, 2003). It is known since the Middle Pleistocene of France, and from a number of Late Pleistocene localities of the UK, Spain, France, Italy, Austria and Hungary (Tyrberg, 1998a, 1998b). Biśnik Cave represents the most north-easterly situated fossil site of the species.

The Parrot Crossbill (Loxia pytyopsittacus) Nowadays it breeds in the pine forests of northwest Europe and into western Russia. It is mainly resident, but will irrupt south and west if its food source fails; a very rare vagrant to Poland (Cramp and Perrins, 1994). This species has been known since the Middle Pleistocene of France, and from several Late Pleistocene sites of France, Italy and the Czech Republic (Tyrberg, 1998a, 1998b). Biśnik Cave is the northern-most fossil site of the species. 
TOMEK ET AL.: ORNITHOFAUNA OF BIŚNIK CAVE

TABLE 3. Not fully ossified specimens of subadult and/or immature birds found in successive layers in Biśnik Cave.

\begin{tabular}{|c|c|c|c|c|c|c|c|c|c|c|c|c|c|c|c|c|}
\hline \multirow{2}{*}{$\begin{array}{l}\dot{0} \\
\mathbf{z} \\
\underset{\mathbb{x}}{\mathbb{N}} \\
\end{array}$} & \multirow{2}{*}{ Taxon } & \multicolumn{2}{|c|}{$\begin{array}{l}\frac{x}{x} \\
\frac{0}{0} \\
\frac{0}{\varepsilon} \\
0\end{array}$} & 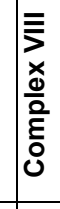 & 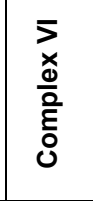 & \multicolumn{2}{|c|}{ 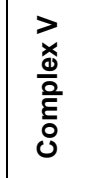 } & \multirow{2}{*}{ 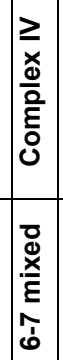 } & \multicolumn{2}{|c|}{$\begin{array}{l}\equiv \\
\bar{x} \\
\frac{0}{0} \\
\stackrel{0}{\Xi} \\
\mathcal{0}\end{array}$} & \multirow{2}{*}{ 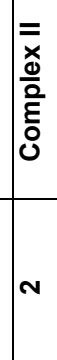 } & \multirow{2}{*}{\begin{tabular}{|l}
$\bar{x}$ \\
$\frac{\mathbf{x}}{0}$ \\
$\frac{0}{\varepsilon}$ \\
ơ \\
-
\end{tabular}} & \multicolumn{3}{|c|}{ 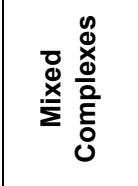 } & \multirow{2}{*}{$\begin{array}{l}\bar{\pi} \\
\text { 。ㅇ }\end{array}$} \\
\hline & & $\stackrel{9}{2}$ & $\stackrel{\infty}{\infty}$ & $\stackrel{2}{2}$ & $\begin{array}{l}m \\
\stackrel{m}{\Phi} \\
\stackrel{x}{E}\end{array}$ & 은 & 0 & & 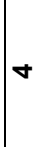 & 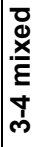 & & & 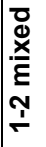 & 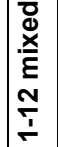 & a. & \\
\hline 1 & cf. Anas strepera & & & & & & & & & & & & & 1 & & 1 \\
\hline \multirow[t]{2}{*}{2} & Anas platyrhynchos & & & & & & 1 & & & & & & 1 & & & 2 \\
\hline & cf. Anas platyrhynchos & & & & & & & & & & 1 & & & & & 1 \\
\hline 3 & Anas querquedula/crecca & & & & & & & & & & & & & & 1 & 1 \\
\hline \multirow[t]{2}{*}{4} & Melanitta nigra & & & & & & & & & & & & & & 1 & 1 \\
\hline & Anatinae indet. & & & & & & 1 & & & & & & & & & 1 \\
\hline 5 & Buteo buteo/lagopus & & & & & & & & & & & & 1 & & 2 & 3 \\
\hline \multirow[t]{2}{*}{6} & Falco tinnunculus & & 1 & & & & & & & & 2 & 1 & & 2 & 9 & 15 \\
\hline & Falco cf. tinnunculus & & & & & & & & & & & & & 2 & 2 & 4 \\
\hline \multirow[t]{3}{*}{7} & Falco peregrinus & & & & & & & & & & & & & & 1 & 1 \\
\hline & Falco sp. & & & & & & & 1 & & & & & 1 & 2 & 3 & 7 \\
\hline & Falconiformes small size & & & & & & & & & & & & 1 & & & 1 \\
\hline \multirow[t]{2}{*}{8} & Lagopus lagopus & & & & & 1 & & & & & & & & & & 1 \\
\hline & Lagopus sp. & & & & 1 & & & & & & & & & 1 & & 2 \\
\hline 9 & Tetrao tetrix & & & & 1 & & & & & & 5 & & 1 & & 2 & 9 \\
\hline \multirow[t]{2}{*}{10} & Tetrao urogallus & & & & & & & & & & & & 1 & & 1 & 2 \\
\hline & Tetrao/Lagopus & & & & & & & & & & 1 & & & & & 1 \\
\hline \multirow[t]{2}{*}{11} & Gallus gallus & & & & & & & & & & & 1 & & & 10 & 11 \\
\hline & Galliformes indet & & & & & & & & & & & & 1 & & 3 & 4 \\
\hline 12 & Rallus aquaticus & & & & & & & & & & & & 1 & & & 1 \\
\hline 13 & Strix aluco & & & & & & & & & & 1 & & & & & 1 \\
\hline \multirow[t]{2}{*}{14} & Asio flammeus/Asio otus & & & & & & & & & & & & 1 & & & 1 \\
\hline & Strigiformes middle size & & & & & & & & & & & & 1 & & & 1 \\
\hline 15 & Hirundo/Cecropis & & 1 & & & & & & & & & & & & & 1 \\
\hline 16 & Anthus sp. & 1 & & & & & & & & & & & & & & 1 \\
\hline \multirow[t]{3}{*}{17} & Turdus viscivorus & & & & & & & & & & & & & 1 & & 1 \\
\hline & Turdus viscivorus/pilaris & & & & & & & & & & & 1 & & & & 1 \\
\hline & Turdus sp. & & & & & & & & & & & 1 & & & & 1 \\
\hline 18 & cf. Luscinia sp. & & & & & & & & & & & & & 1 & & 1 \\
\hline & Turdidae (small) indet. & & & & 1 & & & & & 1 & & & & & & 2 \\
\hline 19 & cf. Sylvia sp. & & & & & & & & & & 1 & & & & & 1 \\
\hline 20 & Corvus monedula & & & 1 & & & 1 & & & & & & & & 7 & 9 \\
\hline & Corvus monedula/Pyrrhocorax & & & 8 & & & & & & & & & & & & 8 \\
\hline & Corvidae (small) indet. & & & 7 & & & 1 & 1 & 2 & & 2 & 1 & 1 & 3 & 7 & 25 \\
\hline 21 & Corvus corax & & & & & & & & & & & & & & 1 & 1 \\
\hline & Aves indet & & & & & & & & & & & & & & 1 & 1 \\
\hline & Total & 1 & 2 & 16 & 3 & 1 & 4 & 2 & 2 & 1 & 13 & 5 & 11 & 13 & 51 & 125 \\
\hline
\end{tabular}




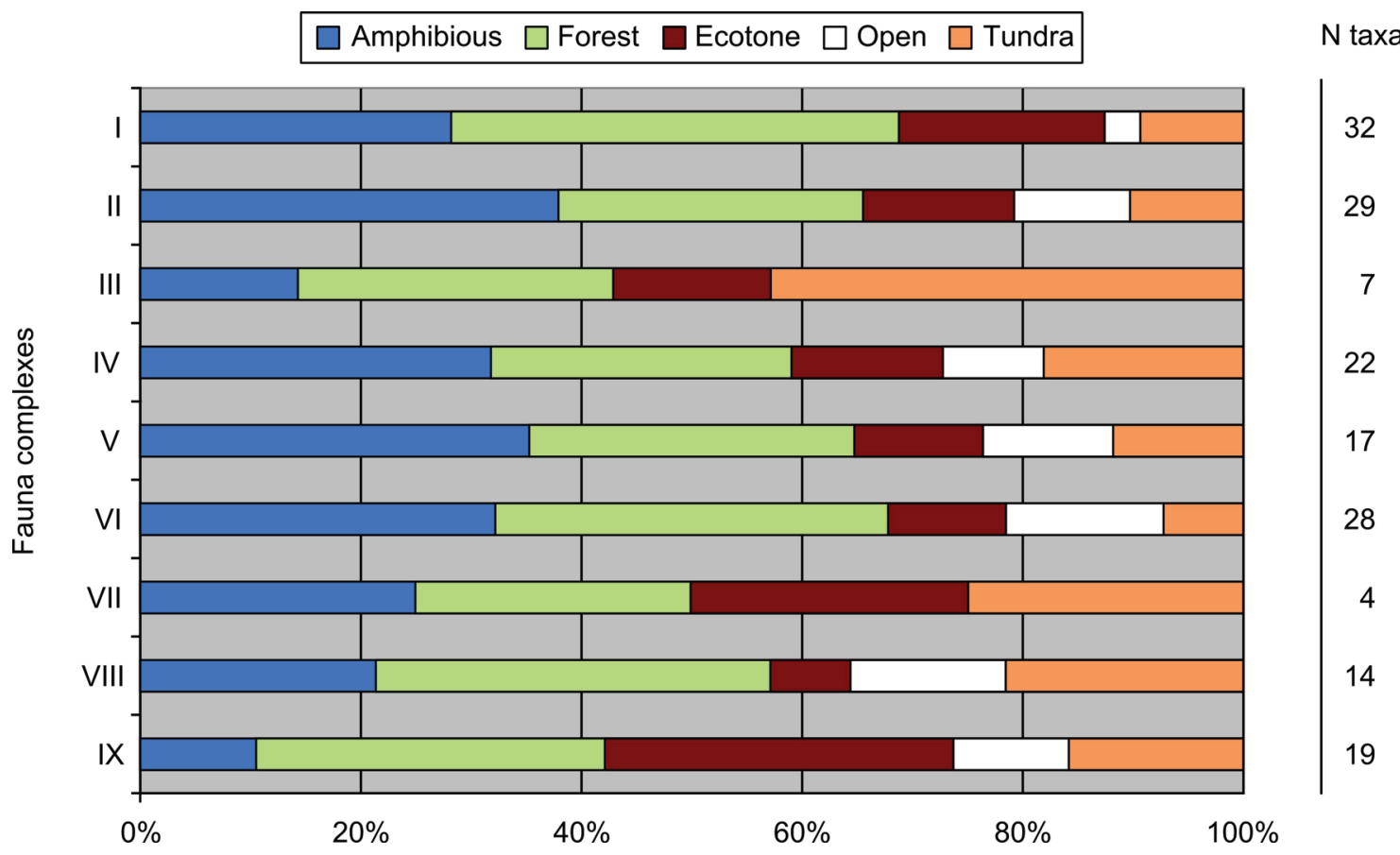

FIGURE 3. Percentage share of bird taxa (numbers of taxa) breeding in five groups of habitats, excavated in particular layers in Biśnik Cave (based on data from Table 2). The correlation between particular fauna complexes and their geological age is explained in Table 1.

The Common Redpoll (Carduelis flammea) Nowadays it breeds across the northern parts of Eurasia and North America, and migrates further south in winter into most of Eurasia, southern Canada and the northern USA (Cramp and Perrins, 1994). In Poland it is an extremely scarce and local breeder; more common in winter and on migrations (Tomiałojć and Stawarczyk, 2003). This species has been known since the Middle Pleistocene of France, and from a number of Late Pleistocene sites of France, Italy and the UK (Tyrberg, 1998a, 1998b). Biśnik Cave represents the most northeasterly situated fossil site of the species.

\section{Other Taxonomic Comments}

Falco tinnunculus atavus Jánossy, 1972 is known from numerous European localities from the Early to the Middle Pleistocene (Tyrberg, 1998a, $1998 b)$. Its presence was also confirmed in one site in Poland - Kozi Grzbiet (Bocheński, 1984). Its remains differ from the recent Falco tinnunculus by being considerably larger (Jánossy, 1972, 1978), which was also the case of the two specimens from Biśnik Cave. Both specimens were close to the maximum size of F.tinnunculus atavus (MourerChauviré, 1975). Although the two specimens were recovered from mixed sediments and their precise stratigraphy is unknown, it is clear that Falco tinnunculus atavus must have coexisted with the recent form of Falco tinnunculus because remains of the latter were found in nearly all of the fauna complexes of Biśnik Cave - from the Odra Glacial to the Holocene.

Of the 13 specimens identified as Hirundol Cecropis six were within the size range of Hirundo rustica but seven others were clearly larger. The large specimens were found in various sediments that cover the time span from the Lubawa Interglacial, through the Warta Glacial, Eemian, Early Vistula Glacial to the Upper Plenivistulian. Theoretically the larger specimens may represent Hirundo rupestris (Cramp, 1988) but the species is rare in skeletal collections, and the specimens we were able to check were not larger than those of Hirundo rustica. Finally, it is also possible that the large fossils represent an extinct (sub)species, an option that needs further studies. So far no extinct members of the Hirundinidae are known from the Pleistocene of the Palearctic (Tyrberg, 1998a, 1998b).

Remains dated to the Eemian and older periods are of special interest because many of them represent the oldest findings of particular species in the avifauna of Poland. Their identification was 
performed carefully to avoid possible mistakes with extinct species that are known to have occurred in those times. For instance, in the case of galliforms we excluded the possible presence of Lagopus lagopus atavus because it was smaller than Lagopus lagopus (Jánossy, 1974a), and its remains are known from the Pliocene only (Tyrberg, 1998a, 1998b). Also Tetrao partium was excluded not only because its dimensions are intermediate between recent Tetrao tetrix and Lagopus lagopus (Kretzoi, 1961; Jurcsák and Kessler, 1987; Boev, 1999) but also because it differs in some morphological characters (e.g., Boev, 1999). All potentially "suspicious" remains from Biśnik Cave were within the size ranges of either Tetrao tetrix or Lagopus lagopus and, in case of better preserved specimens, showed characters typical to one of the two recent species (Boev, 1999; Bocheński and Tomek, 2000). Similarly, Bonasa (Tetrastes) praebonasia was excluded because it was somewhat larger than the recent Bonasa bonasia (Jánossy, 1974b; Bocheński, 1984), and the specimen from the Odra Glaciation of Biśnik Cave (proximal ulna) was close to the lower size range of recent females (Kraft, 1972).

Most species identified in Biśnik Cave belong to the modern avifauna of Poland (Tomiałojć and Stawarczyk, 2003). The few species that do not occur in Poland nowadays are found either in (northern) Scandinavia where they live in taiga and/or tundra (Falco rusticolus, Lagopus lagopus, Lagopus muta, Charadrius morinellus, Pluvialis apricaria, Pluvialis squatarola, Arenaria interpres, Surnia ulula, Strix nebulosa, Loxia pytyopsittacus, Pinicola enucleator) or in high mountains (Tachymarptis melba, Pyrrhocorax graculus, Montifringilla nivalis).

Caution is advised to draw far reaching conclusions from the composition of the fauna complex I, which is believed to have accumulated during the Holocene. The complex consists of a thin layer 1 whose remains accumulated probably for several thousand years and, to some extent, they may have been mixed with the top-most Pleistocene layer 2 . Therefore, we cannot be absolutely sure that e.g., the Lagopus species survived long enough to co-exist with Gallus gallus, which was introduced to Europe during the last centuries BC. The co-existence of the two species during the Holocene was suggested at several other sites in Poland including Komarowa Cave (Tomek and Bocheński, 2005), Rock-shelter in Krucza Skała (Bocheński and Tomek, 2004) and Obłazowa Cave
(Tomek et al., 2003). The problem could only be solved by $14 \mathrm{C}$ dating.

All not fully ossified bones (Table 3 ) belonged to birds that were sufficiently developed to fly. Although some of them could die during migration, they still indicate a certain type of habitat because in Europe migrating birds breed in the north and spend winter in the south. Therefore, the young specimens most probably represent breeding fauna because during the Pleistocene areas north of Biśnik Cave were less suitable for breeding due to the ice sheet that covered most of northern Europe.

\section{Habitat and Avifauna Changes}

The share of avian taxa living in water and other humid habitats fluctuated but generally increased from the Odra Glacial to the Upper Plenivistulian, which is especially evident if we exclude data from the least numerous complexes III and VII where the number of taxa was lower than 10. Open water bodies must have been present at least since the Lubawa Interglacial (fauna complex VIII), which is confirmed by the presence of ducks in this and all subsequent fauna complexes. Ducks must have bread nearby, which is indicated by remains of not fully ossified birds recovered from the Early Vistulian and Upper Plenivistulian (fauna complexes $\mathrm{V}$ and II). The present data generally agree with those obtained on the basis of mammalian remains (Socha, 2009; Cyrek et al., 2010) - the studies point to the constant presence of water bodies in the surroundings of Biśnik Cave. However, the share of avian and mammalian taxa connected with humid environments differed in particular fauna complexes. During the Holocene (fauna complex I) the share of avian taxa connected with water remained at a relatively high level. The latter conclusion does not agree with the observations from nearby sites of Rock-shelter in Krucza Skała (Bocheński and Tomek, 2004) and Komarowa Cave (Tomek and Bocheński, 2005) where the share of water-andmarsh bird species evidently decreased indicating gradual drainage. The discrepancies are difficult to explain; they can be due to the thin Holocene layer in Biśnik Cave and/or local differences in the presence of water-and-marsh habitats.

Typical forest birds were identified in all fauna complexes including those which yielded few avian remains (i.e., complex VII - Warta Glacial, and complex III - Middle Plenivistulian). This indicates the presence of forests during the entire time of sedimentation. The share of forest species was rel- 
atively stable - particular fauna complexes show little variation in this respect. Remains of birds that require old mature forests as breeding habitats were found in nearly all fauna complexes (the exceptions were the fauna complexes VII and III). One such species is the capercaillie Tetrao urogallus whose remains were present during the Odra Glacial (complex IX), Eemian (VI), Early Vistulian (V), Lower Plenivistulian (IV) and the Holocene (I). It is a species typical of taiga mature forest. The presence of old mature forests is also confirmed by the remains of other species in subsequent periods: the Odra Glacial (Scolopax rusticola, Columba palumbus and Corvus corax), the Lubawa Interglacial (Dendrocopos major, Nucifraga caryocatactes and Loxia pytyopsittacus), Eemian (Scolopax rusticola, Strix uralensis, Corvus corax, Loxia cf. curvirostra, cf. Coccothraustes coccothraustes), Early Vistulian (Tetrao urogallus, Strix uralensis, Corvus corax, Loxia cf. curvirostra), Lower Plenivistulian (Garrulus glandarius), Upper Plenivistulian (Scolopax rusticola, Columba palumbus, Dryocopus martius, Corvus corax) and the Holocene (Columba palumbus, Aegolius funereus, Garrulus glandarius, Loxia sp., Coccothraustes coccothraustes). The remaining species listed in category "forest" (Table 2) do not require old trees for breeding. Remains of not fully ossified Tetrao tetrix found in the Eemian and Upper Plenivistulian sediments (fauna complexes VI and II) additionally confirm the presence of forest during those periods because $T$. tetrix is a sedentary species that stays in the same area all year round. The present results on avian fauna are in accordance with those on mammalian species from Biśnik Cave where the share of forest taxa was also relatively stable in all fauna complexes except the Holocene when a considerable increase in the share of forest taxa took place (Cyrek et al., 2010 , figure 10). Similarly, an increase of the share of forest avian taxa was reported from nearby Holocene sites (Bocheński and Tomek, 2004; Tomek and Bocheński, 2005) but more detailed comparisons are not possible due to the lack of distinguished layers within the Holocene material of Biśnik Cave.

The share of species characteristic for ecotone habitats fluctuated considerably in the older periods, with Odra Glacial and Warta Glacial being well represented whereas the Lubawa Interglacial showed relatively few ecotone taxa. Remains of two species, Falco tinnunculus and Corvus monedula were found in most fauna complexes; other species were accidental. Members of this ecological group in all fauna complexes indicate that two types of habitats - forests and open areas - must have been present in the surroundings of Biśnik Cave during the entire time of sedimentation.

The number of species living in open habitats ranges from zero during the Warta Glacial and Middle Plenivistulian (which may be connected with the small total number of taxa recorded in fauna complexes VII and III) to four during the Eemian (fauna complex $\mathrm{VI}$ ). The somewhat unexpected increase of the number of taxa associated with open habitats in the Eemian suggests that the four taxa accumulated at the end of the Eemian (layer 12) when the forest areas shrank and the climate conditions became harsher than at the time of deposition of layer 13 - a similar increase was observed in the number of steppe and steppe-tundra mammals (Cyrek et al., 2010). One of the three species characteristic for open steppe habitats (Alauda arvensis, Coturnix coturnix and Perdix perdix) was present in six out of nine consecutive periods since the Odra Glacial to the Holocene (fauna complexes IX, VIII, VI, V, IV and I). Remains of Montifringilla nivalis, which is a high-altitude montane form, confirm that the deposition of fauna complex II took place during a cold period (Upper Plenivistulian). The share of avian species characteristic for open habitats was relatively small and fluctuating but one must remember that tundra may be treated as an open habitat as well. The present results on avian fauna support the conclusions reached for the mammalian fauna of Biśnik Cave where the steppe taxa were found in all periods but their share was always small (Stefaniak et al., 2009; Socha, 2009; Cyrek et al., 2010). Our results (relatively few species connected with open habitats) differ dramatically from those in other regions where birds living in open areas including rocky mountains are usually proportionally more abundant. For example the chronoclimatical sequence of the cave of Gigny-sur-Suran, in the French Jura, includes Pleistocene layers where the share of birds living in open habitats is between 50 and $78 \%$ (Campy et al., 1989; Mourer-Chauviré, 1989).

Of the 11 taxa typical for tundra nine were ascribed to particular fauna complexes (two others lack stratigraphy). Two species were particularly common - Lagopus lagopus was present in all fauna complexes and Lagopus muta was missing only in the materials from the Warta Glacial and Eemian. Remains of other tundra species (cf. Branta bernicla, Falco cf. rusticolus, cf. Charadrius morinellus, Pluvialis apricaria, Pluvialis squatarola, Arenaria interpres, Carduelis flammea) were found in one or two fauna complexes each. The share of 
tundra species fluctuated. It was particularly small during the Eemian (fauna complex $\mathrm{VI}$ ), which can be explained by the development of vegetation due to the warmer climate. An opposite trend was observed during the Middle Plenivistulian (fauna complex III) when the share of tundra species was particularly big. Although it can be an accidental distribution (few avian taxa from that period), it agrees with the data on mammalian fauna where tundra forms were the most numerous (Cyrek et al., 2010, p.17). The present results and those of mammalian fauna from Biśnik Cave have one more thing in common - in both studies tundra species were present in all fauna complexes distinguished.

Temperature rise of a few Centigrades (which took place e.g., during the Eemian) does not have a dramatic impact on temperate avifaunas, and it may be barely if at all detectable in the avifauna (Tyrberg, 2010). The type of habitat and its humidity seem to have a larger effect on the local avifauna than the climate alone (Bocheński, 2000). This could partly explain relatively small changes in the avifauna of Biśnik Cave during the last 300,000 years. It must also be remembered that particular layers of sedimentation or fauna complexes in Biśnik Cave cover relatively long periods of time, and therefore the data are not very sensitive to changes of the habitat. As noticed by Müller et al. (2003) "if climate deteriorations were not long or severe enough to extirpate refugia of arboreal taxa north of the Alps (...), reforestation with the beginning of the warmer conditions in Central Europe occurred on a centennial scale. If arboreal taxa became completely extinct north of the Alps such as during MIS $4(\ldots)$, several thousand years were necessary for the reimmigration from refugia situated in regions south of the Alps." Due to the relative scarcity of avian remains from particular layers in Biśnik Cave, episodes of deforestation that lasted for only a few hundred (and in some cases even thousand) years may not be detectable from the avian remains at all. However, mammalian remains are more numerous (Socha, 2009; Stefaniak et al., 2009; Cyrek et al., 2010), and they indicate the presence of similar habitats as birds.

In summary, all fauna complexes included avian taxa that indicate a mosaic of various habitats in the surroundings of Biśnik Cave. Some kind of mature forest or at least sparsely growing trees, as well as water bodies, marshes, wet meadows, steppe and tundra habitats must have been present during the entire time of sedimentation. This is in agreement with the results obtained from the analysis of mammalian fauna from Biśnik Cave (Cyrek et al., 2010; Van Asperen and Stefaniak, 2011) and other localities of the KrakówCzęstochowa Upland (Stefaniak et al., 2009). Even during the coldest periods small and large mammals typical for forest environments or associated with dense vegetation were present in the area. Although the number of forest species and their proportion in the fauna varied, they were constantly present in the Kraków-Częstochowa Upland, which is thought to have been a local refugium for the forest fauna during the Saalian (i.e., the Odra and Warta glacial periods) and Vistulian glaciations (Stefaniak et al., 2009; Van Asperen and Stefaniak, 2011). Due to its geographic location, the region was probably a transition zone between the steppe habitats of Central Asia and the more oceanic environments of Western Europe. Our results on avian remains support the hypothesis.

\section{ACKNOWLEDGMENTS}

The study was partially supported by the Ministry of Science and Higher Education of Poland, grant no. N N109318237. We thank M. Lorenc for fruitful discussions on the earlier version of the paper and the following curators for making available modern comparative specimens: $Z$. Boev (NMNHS), J. B. Kristensen (ZMUC), H. Obermaier (SAP) and R. Tornberg (ZMUO).

\section{REFERENCES}

Bocheński, Z. 1984. Middle Pleistocene remains of birds from Kozi Grzbiet in the Świętokrzyskie Mts. (Holy Cross Mts. - Central Poland). Acta Zoologica Cracoviensia, 27:177-186.

Bocheński, Z. 2000. Interpretacja składu gatunkowego zespołu ptaków dzikich, p. 84-98. In Bocheński, Z. (ed.), Podstawy archeozoologii. Ptaki. Wydawnictwo Naukowe PWN, Warszawa.

Bocheński, Z.M. 2008. Identification of skeletal remains of closely related species: the pitfalls and solutions. Journal of Archaeological Science, 35:1247-1250.

Bocheński, Z.M. and Tomek, T. 1995. How many comparative skeletons do we need to identify a bird bone? Courier Forschungsinstitut Senckenberg, 181:357-361.

Bocheński, Z.M. and Tomek, T. 2000. Identification of bones of Galliform hybrids. Journal of Archaeological Science, 27:691-698.

Bocheński, Z. and Tomek, T. 2004. Bird remains from a rock-shelter in Krucza Skała (Central Poland). Acta Zoologica Cracoviensia, 47(1-2):27-47. 
Bocheński, Z.M. and Tomek, T. 2009. A key for the identification of domestic birds bones in Europe: preliminary determination. Institute of Systematics and Evolution of Animals, Kraków.

Boev, Z. 1999. On the presence of Tetrao partium (Kretzoi, 1962) (Aves: Tetraonidae) in the Late Pliocene of Bulgaria. Historia naturalis bulgarica, 10:85-96.

Campy, M., Chaline, J., Heim, J., Mourer-Chauviré, C., and Vuillemey, M. 1989. La séquence chronoclimatique de Gigny, p. 243-251. In La Baume de Gigny (Jura) sous la direction de M. Campy, J. Chaline et M. Vuillemey. XXVII ème suppl. à Gallia-Préhistoire, CNRS édit., Paris.

Cramp, S. 1988. Handbook of the Birds of Europe, the Middle East and North Africa; The Birds of the Western Paleartic, vol. V. Oxford University Press, Oxford.

Cramp, S. and Perrins, C.M. (eds.). 1994. Handbook of the Birds of Europe, the Middle East and North Africa; The Birds of the Western Paleartic, vol. VIII. Oxford University Press, Oxford.

Cramp, S. and Simmons, K.E.L. (eds.). 1980. Handbook of the Birds of Europe, the Middle East and North Africa; The Birds of the Western Paleartic, vol. II. Oxford University Press, Oxford.

Cyrek, K. 2002. Jaskinia Biśnik. Rekonstrukcja zasiedlenia jaskini na tle zmian środowiska przyrodniczego. Wydawnictwo Uniwersytetu Mikołaja Kopernika, Toruń.

Cyrek, K. 2003. Biśnik Cave: a reconstruction of the site's occupation in the context of environmental changes. Eurasian Prehistory, 1(1):5-29.

Cyrek, K., Mirosław-Grabowska, J., Stefaniak, K., and Socha, P. 2009. Archaeology, stratigraphy and palaeoecology of the Biśnik Cave, p. 191-214. In Stefaniak, K., Tyc, A., and Socha, P. (eds.), Karst of the Częstochowa Upland and of the Eastern Sudetes: palaeoenvironments and protection. Studies of the Faculty of Earth Sciences, University of Silesia, 56, Sosnowiec - Wrocław.

Cyrek, K., Socha, P., Stefaniak, K., Madeyska, T., Mirosław-Grabowska, J., Sudoł, M., and Czyżewski, Ł. 2010. Palaeolithic of Biśnik Cave (Southern Poland) within the environmental background. Quaternary International, 220:5-30.

Jánossy, D. 1972. Die mittelpleistozäne Vogelfauna der Stránská Skála. Anthropos, 20(N.S.12):35-64.

Jánossy, D. 1974a. Upper Pliocene and Lower Pleistocene bird remains from Poland. Acta Zoologica Cracoviensia, 19(21):531-564.

Jánossy, D. 1974b. Die mittelpleistozäne Vogelfauna von Hundsheim (Niederösterreich). Sitzungsberichte der Österreichischen Akademie der Wissenschaften, Mathematisch-Naturwissenschaftliche Klasse, Abt. I, 182(6-8):211-257.

Jánossy, D. 1978. Plio-Pleistocene bird remains from the Carpathian basin III. Strigiformes, Falconiformes, Caprimulgiformes, Apodiformes. Aquila, 84:9-36.
Jenner, B., Bocheński, Z.M., and Tomek, T. 2001. Relative differentiation of skeletal elements in European corvids. Journal für Ornithologie, 142:30-33.

Jurcsák, T. and Kessler, E. 1987. Evolutia Avifaunei pe teritoriul Românei. II. Morfologia speciilor fosile. Crisia, 17:583-609.

Kowalski, K. 1951. Jaskinie Polski, vol.1. Państwowe Muzeum Archeologiczne, Warszawa.

Kraft, E. 1972. Vergleichend morphologische Untersuchungen an Einzelknochen nord- und mitteleuropäischer kleinerer Hühnervögel. Ph.D. Thesis, LudwigMaximilians-Universität München.

Kretzoi, M. 1961. Vogelreste aus der altpleistozänen Fauna von Betfia. Aquila, 67-68:167-174.

Krewsun, M. 2003. Czwartorzędowa fauna kręgowców z osadów jaskiniowych Doliny Wodącej, p. 87-94. In Maciak, S., Mazurek, Ł., and Chętnicki, W. (eds.), Materiały VII Ogólnopolskiego Przeglądu Działalności Studenckich Kół Naukowych Przyrodników. Białystok.

Lyman, R.L. 2008. Quantitative Paleozoology. Cambridge Manuals in Archaeology. Cambridge University Press, Cambridge.

Madeyska, T. and Cyrek, K. 2002. Cave fillings - a chronicle of the past. An outline of the Younger Pleistocene cave sediments study in Poland. Acta Geologica Polonica, 52:75-95.

Marciszak, A. and Stefaniak, K. 2010. Two forms of cave lion: Middle Pleistocene Panthera spelaea fossilis Reichenau, 1906 and Upper Pleistocene Panthera spelaea spelaea Goldfuss, 1810 from the Biśnik Cave. Neues Jahrbuch für Geologie und Paläontologie, 258:339-351.

Mirosław-Grabowska, J. 2002. Geological value of Biśnik Cave sediments (Cracow-Częstochowa Upland). Acta Geologica Polonica, 52:97-110.

Mourer-Chauviré, C. 1975. Les oiseaux de Pléistocène moyen et supérieur de France. Documents des Laboratoires de Géologie de la Faculté des Sciences de Lyon, 64(parts 1 and 2):1-261, 263-624.

Mourer-Chauviré, C. 1989. Les Oiseaux, p. 121-129. In La Baume de Gigny (Jura) sous la direction de $\mathrm{M}$. Campy, J. Chaline et M. Vuillemey. XXVII ème suppl. à Gallia-Préhistoire, CNRS édit., Paris.

Müller, U.C., Pross, J., and Bibus, E. 2003. Vegetation response to rapid climate change in Central Europe during the past 140,000 yr based on evidence from the Füramoos pollen record. Quaternary Research, 59:235-245.

Nadachowski, A., Żarski, M., Urbanowski, M., Wojtal, P., Miękina, B., Lipecki, G., Ochman, K., Krawczyk, M., Jakubowski, G., and Tomek, T. 2009. Late Pleistocene environment of the Częstochowa Upland (Poland) reconstructed on the basis of faunistic evidence from archaeological cave sites. Institute of Systematics and Evolution of Animals, Polish Academy of Sciences, Kraków. 
Pike, A.E.G. and Hedges, R.E.M. 2001. Sample geometry and $U$ uptake in archaeological teeth: implications for U-series and ESR dating. Quaternary science reviews, 20:1021-1025.

Socha, P. 2009. Small mammals (Erinaceomorpha, Soricomorpha, Chiroptera, Lagomorpha, Rodentia) from Pleistocene sediments of the Biśnik Cave, p. 215224. In Stefaniak, K., Tyc, A., and Socha, P. (eds.), Karst of the Częstochowa Upland and of the Eastern Sudetes: palaeoenvironments and protection. Studies of the Faculty of Earth Sciences, University of Silesia, 56, Sosnowiec - Wrocław.

Stefaniak, K. and Marciszak, A. 2009. Large mammals (Carnivora, Ungulata) from Pleistocene sediments of the Biśnik Cave, p. 225-254. In Stefaniak, K., Tyc, A., and Socha, P. (eds.), Karst of the Częstochowa Upland and of the Eastern Sudetes: palaeoenvironments and protection. Studies of the Faculty of Earth Sciences, University of Silesia, 56, Sosnowiec Wrocław.

Stefaniak, K., Nadachowski, A., Tomek, T., and Socha, P. 2009. Palaeontological studies in the Częstochowa Upland, p. 85-144. In Stefaniak, K., Tyc, A., and Socha, P. (eds.), Karst of the Częstochowa Upland and of the Eastern Sudetes: palaeoenvironments and protection. Studies of the Faculty of Earth Sciences, University of Silesia, 56, Sosnowiec - Wrocław.

Tomek, T. and Bocheński, Z. 2005. Weichselian and Holocene bird remains from Komarowa Cave, Central Poland. Acta Zoologica Cracoviensia, 48A(12):43-65.

Tomek, T. and Bocheński, Z.M. 2000. The comparative osteology of European corvids (Aves: Corvidae), with a key to the identification of their skeletal elements. Publications of the Institute of Systematics and Evolution of Animals, Kraków.

Tomek, T. and Bocheński, Z.M. 2009. A key for the identification of domestic bird bones in Europe: Galliformes and Columbiformes. Institute of Systematics and Evolution of Animals, Kraków.
Tomek, T., Bocheński, Z., and Bocheński, Z.M. 2003. Birds (Aves), p. 102-113. In: Valde-Novak, P., Nadachowski, A., and Madeyska, T. (eds.), Obłazawa Cave: human activity, stratigraphy and palaeoenvironment. Institute of Archaeology and Ethnology Polish Academy of Sciences, Kraków.

Tomiałojć, L. and Stawarczyk, T. 2003. Awifauna Polski. Rozmieszczenie, liczebność i zmiany. PTPP „pro Natura, Wrocław.

Tyrberg, T. 1998a. Pleistocene Birds of the Palaearctic: A Catalogue. Publications of the Nuttall Ornithological Club, No. 27, Cambridge, Massachusetts.

Tyrberg, T. 1998b. Pleistocene Birds of the Palaearctic: A Catalogue. Publications of the Nuttall Ornithological Club, No. 27, Cambridge, Massachusetts. Updates at http://web.telia.com/ u11502098/pleistocene.pdf (accessed 2011-03-17).

Tyrberg, T. 2010. Avifaunal responses to warm climate: The message from Last Interglacial fauns. Records of the Australian Museum, 62:193-205.

Van Asperen, E.N. and Stefaniak, K. 2011. Biśnik Cave and its biostratigraphical position based on equid remains. Acta Zoologica Cracoviensia, 54A(1-2):5576.

Wiszniowska, T., Socha, P., and Stefaniak, K. 2001. Czwartorzędowa fauna kręgowców jaskiń Doliny Wodącej., p. 321-326. In Partyka, J. (ed.), Badania Naukowe w południowej części Wyżyny KrakowskoCzęstochowskiej, Ojców.

Wiszniowska, T., Socha, P., and Stefaniak, K. 2002. Czwartorzędowa fauna z osadów Jaskini Biśnik, $p$. 192-229. In Cyrek, K. (ed.), Jaskinia Biśnik. Rekonstrukcja zasiedlenia jaskini na tle zmian środowiska przyrodniczego. Wydawnictwo Uniwersytetu Mikołaja Kopernika, Toruń.

Wiszniowska, T., Socha, P., and Stefaniak, K. 2004. Czwartorzędowe szczątki kręgowców z osadów jaskiń Wyżyny Częstochowskiej jako wskaźniki zmian środowiska, p. 61-63. In Muszer, E. (ed.), Zapis paleontologiczny jako wskaźnik paleośrodowisk. Wrocław. 
TABLE 2a. Bird remains identified in layers 19-8 (fauna complexes IX-V) in Biśnik Cave. Categories of habitat (see Material and Methods): A, amphibious; E, ecotone; F, forest; $\mathrm{O}$, open; $\mathrm{T}$, tundra. To exclude double counting of remains, before computing the minimum number of individuals (MNI) for mixed complexes it was always checked whether the remains from mixed sediments may have belonged to birds from layers with well-defined stratigraphy.

\begin{tabular}{|c|c|c|c|c|c|c|c|c|c|c|c|c|c|c|c|c|c|c|c|}
\hline \multirow[b]{3}{*}{ 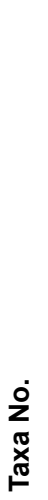 } & \multirow{3}{*}{ Taxon } & \multirow[b]{3}{*}{$\begin{array}{l}\frac{\pi}{5} \\
\frac{\pi}{0} \\
\frac{\pi}{1}\end{array}$} & \multicolumn{3}{|c|}{$\begin{array}{l}\underset{x}{x} \\
\frac{0}{0} \\
\frac{0}{E} \\
0\end{array}$} & \multicolumn{2}{|c|}{ 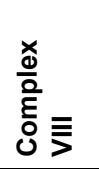 } & \multicolumn{2}{|c|}{ 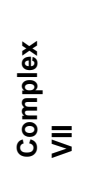 } & \multicolumn{4}{|c|}{$\begin{array}{l}\bar{x} \\
\frac{x}{0} \\
\frac{0}{\varepsilon} \\
0 \\
0\end{array}$} & \multicolumn{5}{|c|}{$\begin{array}{l}> \\
\text { o } \\
\frac{0}{0} \\
\text { है }\end{array}$} & \\
\hline & & & \multicolumn{2}{|r|}{$\frac{0}{2}$} & \multirow{2}{*}{ 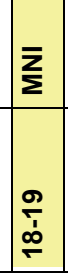 } & \multirow{2}{*}{$\begin{array}{l}\frac{0}{\mathbf{0}} \\
\stackrel{\infty}{\sim}\end{array}$} & \multirow{2}{*}{\begin{tabular}{|l|}
$\mathbf{z}$ \\
$\underline{\Sigma}$ \\
\end{tabular}} & \multirow{2}{*}{$\begin{array}{l}\frac{0}{0} \\
\mathbf{n} \\
\\
\end{array}$} & \multirow{2}{*}{\begin{tabular}{l|}
$\bar{\Sigma}$ \\
$\Sigma$ \\
\end{tabular}} & \multicolumn{3}{|c|}{$\frac{0}{2}$} & \multirow{2}{*}{$\begin{array}{l}\frac{\Sigma}{\Sigma} \\
\stackrel{m}{\grave{i}} \\
\stackrel{m}{N}\end{array}$} & \multicolumn{4}{|c|}{$\frac{0}{2}$} & \multirow{2}{*}{\multicolumn{2}{|c|}{\begin{tabular}{|l}
$\bar{\Sigma}$ \\
$\bar{\Sigma}$ \\
$\bar{\infty}$
\end{tabular}}} \\
\hline & & & $\stackrel{9}{\square}$ & $\infty$ & & & & & & $\stackrel{m}{=}$ & N & to & & $\mp$ & 우 & 0 & $\infty$ & & \\
\hline \multicolumn{20}{|c|}{ Podicipediformes } \\
\hline 1 & cf. Podiceps cristatus/grisegena & A & & & & & & & & & & & & & & & & & \\
\hline \multicolumn{20}{|c|}{ Anseriformes } \\
\hline 2 & Anser/Branta & A & & & & & & & & & & & & & & 1 & & & 1 \\
\hline 3 & Branta bernicla & $\mathrm{T}$ & & & & & & & & & & & & & & & & & \\
\hline & cf. Branta bernicla & $\mathrm{T}$ & & & & & & & & & & & & & & & & & \\
\hline 4 & Tadorna tadorna & A & & & & & & & & & & & & & & & & & \\
\hline 5 & cf. Anas strepera & A & & & & & & & & & & & & & & & & & \\
\hline 6 & Anas crecca & A & & & & & & & & & & & & & & & & & \\
\hline 7 & Anas platyrhynchos & A & & & & & & & & & & & & & & 1 & & & 1 \\
\hline & cf. Anas platyrhynchos & A & & & & & & 1 & 1 & & & 1 & 1 & & & & & & \\
\hline 8 & Anas querquedula & A & & & & & & & & & & 1 & 1 & & & & & & \\
\hline & Anas querquedula/crecca & A & & & & 1 & 1 & & & & & 1 & 1 & & 4 & & & & 3 \\
\hline 9 & Anas clypeata & A & & & & & & & & & & & & & & & & & \\
\hline & Anas cf. clypeata & A & & & & & & & & & & & & & & & & & \\
\hline & Anas sp. & A & & & & & & & & & & & & & & & & & \\
\hline 10 & Aythya fuligula & A & & & & & & & & & & 1 & 1 & & & & & & \\
\hline 11 & Melanitta nigra & A & & & & & & & & & & & & & & & & & \\
\hline 12 & Melanitta fusca & A & & & & & & & & & & & & & & & & & \\
\hline 13 & Bucephala clangula & $A$ & & & & & & & & & & & & & & & & & \\
\hline & cf. Bucephala clangula & A & & & & & & & & & & & & & & & & & \\
\hline 14 & Mergellus albellus & A & & & & & & & & & & & & & 1 & & & 1 & 2 \\
\hline 15 & cf. Mergus merganser & A & & & & & & & & & & & & & & & & & \\
\hline & Anatinae indet. & A & & & & & & & & & & 1 & & & & 1 & & & \\
\hline Fal & coniformes & & & & & & & & & & & & & & & & & & \\
\hline 16 & Circus sp. & $\mathrm{O}$ & & & & & & & & & & & & & & & & & \\
\hline 17 & Accipiter nisus & $E$ & & & & & & & & & & & & & & & & & \\
\hline & cf. Accipiter nisus & $E$ & & 1 & 1 & & & & & & & & & & & & & & \\
\hline 18 & Accipiter gentilis & $E$ & & & & & & & & & & & & & & & & & \\
\hline 19 & Buteo buteo & $E$ & & & & & & & & & & & & & & & & & \\
\hline & Buteo buteo/lagopus & $E$ & & & & & & & & & & & & & & & & & \\
\hline 20 & cf. Aquila heliaca & $E$ & & & & & & & & & & & & & & & & & \\
\hline & Aquila sp. & $E$ & & & & & & & & & & & & & & & & & \\
\hline 21 & Falco tinnunculus & $E$ & 3 & 2 & 4 & & & & & & & 1 & 1 & & 2 & & & & 1 \\
\hline 22 & Falco tinnunculus atavus & & & & & & & & & & & & & & & & & & \\
\hline
\end{tabular}




\begin{tabular}{|c|c|c|c|c|c|c|c|c|c|c|c|c|c|c|c|c|c|c|c|c|}
\hline \multirow{3}{*}{ 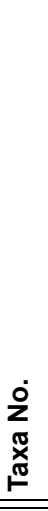 } & \multirow{3}{*}{ Taxon } & \multirow[b]{3}{*}{$\begin{array}{l}\frac{1}{\pi} \\
\frac{\pi}{0} \\
\frac{0}{10} \\
\frac{\pi}{1}\end{array}$} & \multicolumn{4}{|c|}{$\frac{\underline{x}}{\frac{0}{0}}$} & \multicolumn{2}{|c|}{ 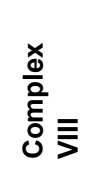 } & \multicolumn{2}{|c|}{ 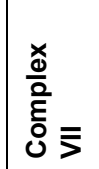 } & \multicolumn{4}{|c|}{$\begin{array}{l}\bar{x} \\
\text { 음 } \\
\text { है }\end{array}$} & \multicolumn{6}{|c|}{ 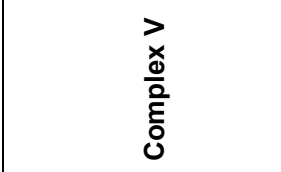 } \\
\hline & & & \multicolumn{3}{|c|}{$\frac{0}{\mathbf{n}}$} & \multirow{2}{*}{ 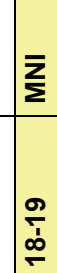 } & \multirow{2}{*}{ 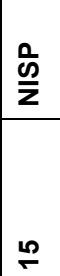 } & \multirow{2}{*}{ 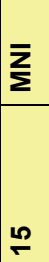 } & \multirow{2}{*}{\begin{tabular}{|l}
$\frac{0}{\text { क्⿹ }}$ \\
$\mathbf{z}$ \\
\multirow{2}{*}{}
\end{tabular}} & \multirow{2}{*}{\begin{tabular}{|l}
$\Sigma$ \\
$\Sigma$ \\
$\Sigma$
\end{tabular}} & \multicolumn{3}{|c|}{$\frac{\hat{0}}{\mathbf{z}}$} & \multirow{2}{*}{ 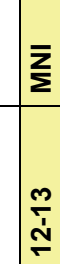 } & \multicolumn{5}{|c|}{$\frac{\hat{0}}{\mathbf{2}}$} & $\overline{\mathbf{z}}$ \\
\hline & & & 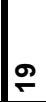 & $\stackrel{\infty}{\sim}$ & مَ & & & & & & $m$ & $\cong$ & $\frac{m}{\stackrel{m}{*}}$ & & $\mp$ & 웅 & a & $\infty$ & 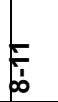 & চ \\
\hline & Falco cf. tinnunculus & $\bar{E}$ & & 1 & & 1 & & & & & & & 1 & 1 & & & & & & \\
\hline 23 & Falco cf. subbuteo & $E$ & & & & & & & & & & & & & & & & & & \\
\hline 24 & Falco peregrinus & $\mathrm{F}$ & & & & & & & & & & & & & & & & & & \\
\hline 25 & Falco cf. rusticolus & $\mathrm{T}$ & 2 & & & 1 & & & & & & & & & & & & & & \\
\hline & Falco sp. & & & 1 & & & & & & & & & & & & & & & & \\
\hline & Falconiformes middle size & & & & & & & & & & & & & & & & & & & \\
\hline & Falconiformes small size & & & & & & & & & & & & & & & & & & & \\
\hline Gal & illiformes & & & & & & & & & & & & & & & & & & & \\
\hline 26 & Lagopus lagopus & $\mathrm{T}$ & 7 & 2 & 1 & 3 & 15 & 2 & 1 & 1 & & 2 & 18 & 3 & & 10 & 12 & 1 & 2 & 5 \\
\hline 27 & Lagopus muta & $\mathrm{T}$ & & 1 & & 1 & 2 & 2 & & & & & & & & 1 & & & 3 & 2 \\
\hline & Lagopus sp. & $\mathrm{T}$ & 8 & & & & 4 & & & & & & 8 & & & 13 & 1 & & 1 & \\
\hline 28 & Tetrao tetrix & $\mathrm{F}$ & 4 & 6 & 3 & 2 & 9 & 2 & 3 & 1 & 2 & 6 & 15 & 3 & 2 & 9 & 2 & & 1 & 3 \\
\hline 29 & Tetrao urogallus & $\mathrm{F}$ & 1 & & & 1 & & & & & 1 & 1 & 2 & 2 & & 2 & & & 5 & 1 \\
\hline & Tetrao sp. & $\mathrm{F}$ & 1 & 1 & & & & & & & & & & & & & & & & \\
\hline & Tetrao/Lagopus & & 3 & & & & & & 1 & & & & 1 & & & & & & 1 & \\
\hline 30 & Bonasa bonasia & $\mathrm{F}$ & & 1 & & 1 & & & & & & & & & & & & & & \\
\hline 31 & Perdix perdix & $\mathrm{O}$ & & & & & & & & & & & & & & & & & 1 & 1 \\
\hline 32 & Coturnix coturnix & $\mathrm{O}$ & & & & & 1 & 1 & & & & & & & & & & & & \\
\hline 33 & Gallus gallus & & & & & & & & & & & & & & & & & & & \\
\hline & Galliformes indet & & & & & & & & 1 & & & & 2 & & & & & & & \\
\hline Gri & uiformes & & & & & & & & & & & & & & & & & & & \\
\hline 34 & Rallus aquaticus & $\mathrm{A}$ & & & & & & & & & & & & & & & & & & \\
\hline 35 & Porzana porzana & $\mathrm{A}$ & & & & & & & & & & & & & & & & & & \\
\hline 36 & Crex crex & A & & & 1 & 1 & 1 & 1 & & & & & & & & & & & & \\
\hline Cha & aradriiformes & & & & & & & & & & & & & & & & & & & \\
\hline 37 & cf. Charadrius morinellus & $\mathrm{T}$ & & & & & & & & & 1 & & & 1 & & & & & & \\
\hline 38 & Pluvialis apricaria & $\mathrm{T}$ & & & & & 2 & 2 & & & & & & & & & & & & \\
\hline 39 & Pluvialis squatarola & $\mathrm{T}$ & & & & & & & & & & & & & & & & & & \\
\hline 40 & Vanellus vanellus & $\mathrm{A}$ & & & & & 1 & 1 & & & & & & & & & & 1 & & 1 \\
\hline & cf. Vanellus vanellus & $\mathrm{A}$ & 1 & & & 1 & & & & & & & & & & & & & & \\
\hline 41 & Philomachus pugnax & A & & & & & & & & & & & 1 & 1 & & & & & & \\
\hline 42 & Gallinago media & $\mathrm{A}$ & & & & & & & & & & & & & & & & & & \\
\hline & cf. Gallinago media & A & & & & & & & & & & & & & & & & & & \\
\hline 43 & Scolopax rusticola & $\mathrm{F}$ & 1 & & & 1 & & & & & & & 2 & 1 & & & & & & \\
\hline 44 & cf. Limosa limosa & $\mathrm{A}$ & & & & & & & & & & & & & & & & & & \\
\hline 45 & Tringa totanus/erythropus & $\mathrm{A}$ & & & & & & & & & & & & & & & & & & \\
\hline 46 & Tringa ochropus & $\mathrm{A}$ & & & & & & & & & & 1 & & 1 & & & & & & \\
\hline 47 & Arenaria interpres & $\mathrm{T}$ & & & & & & & & & & & & & & & & & & \\
\hline 48 & Stercorarius sp. & A & & & & & & & & & & & & & & & & & & \\
\hline 49 & Rissa tridactyla & $\mathrm{A}$ & & & & & & & & & & & & & & & & & & \\
\hline & Charadriiformes indet. & $\mathrm{A}$ & & & & & 3 & & & & & & & & & & & & & \\
\hline
\end{tabular}




\begin{tabular}{|c|c|c|c|c|c|c|c|c|c|c|c|c|c|c|c|c|c|c|c|}
\hline \multirow[b]{3}{*}{$\begin{array}{l}\dot{0} \\
z \\
\mathbb{\pi} \\
\underset{\sigma}{\sigma} \\
\end{array}$} & \multirow{3}{*}{ Taxon } & \multirow[b]{3}{*}{$\begin{array}{l}\frac{\pi}{\pi} \\
\frac{\pi}{0} \\
\frac{\pi}{1} \\
I\end{array}$} & \multicolumn{3}{|c|}{$\frac{\frac{x}{x}}{\frac{x}{0}}$} & \multicolumn{2}{|c|}{ 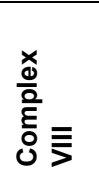 } & \multicolumn{2}{|c|}{ 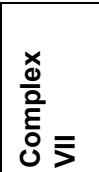 } & \multicolumn{4}{|c|}{ 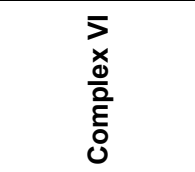 } & \multicolumn{6}{|c|}{$\begin{array}{l}\text { > } \\
\frac{0}{0} \\
\frac{0}{g} \\
\mathcal{\partial}\end{array}$} \\
\hline & & & \multicolumn{2}{|r|}{$\frac{\hat{0}}{2}$} & \multirow{2}{*}{ 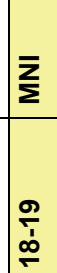 } & \multirow{2}{*}{$\begin{array}{l}\frac{n}{\mathbf{n}} \\
\stackrel{2}{\leftarrow}\end{array}$} & \multirow{2}{*}{$\begin{array}{l}\frac{\bar{z}}{\Sigma} \\
\underline{n}\end{array}$} & \multirow{2}{*}{$\begin{array}{l}\frac{0}{\text { S }} \\
\mathbf{z} \\
\end{array}$} & \multirow{2}{*}{$\begin{array}{l}\sum \bar{\Sigma} \\
\pm \\
\pm\end{array}$} & \multicolumn{3}{|c|}{$\frac{\hat{0}}{\mathbf{n}}$} & \multirow{2}{*}{ 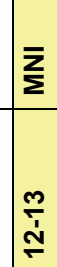 } & \multicolumn{5}{|c|}{$\frac{\hat{0}}{\mathbf{n}}$} & $\overline{\mathbf{z}}$ \\
\hline & & & $\stackrel{9}{-}$ & $\infty$ & & & & & & $\stackrel{m}{\rightleftharpoons}$ & $\simeq$ & - & & $\mp$ & 웅 & 0 & & $\frac{5}{b}$ & $\underset{\infty}{\check{\infty}}$ \\
\hline $\mathrm{Col}$ & umbiformes & & & & & & & & & & & & & & & & & & \\
\hline 50 & Columba palumbus & $\mathrm{F}$ & 1 & & 1 & & & & & & & & & & & & & & \\
\hline$\overline{\mathrm{Cu}}$ & culiformes & & & & & & & & & & & & & & & & & & \\
\hline 51 & Cuculus canorus & $E$ & & & & & & & & & & & & & & & & & \\
\hline Stri & igiformes & & & & & & & & & & & & & & & & & & \\
\hline 52 & Bubo bubo & $\mathrm{F}$ & & & & & & & & & & & & & & & & & \\
\hline 53 & Strix aluco & $E$ & & & & & & & & & & 1 & 1 & & & & & & \\
\hline 54 & Strix uralensis & $\mathrm{F}$ & & & & & & & & 1 & & & 1 & & & & & 1 & 1 \\
\hline 55 & cf. Strix nebulosa & $\mathrm{F}$ & & & & & & & & & & & & & & & & & \\
\hline & cf. Strix sp. & & 1 & & 1 & & & & & & & & & & & & & & \\
\hline 56 & Surnia ulula & $F$ & & & & & & & & & & 2 & 1 & & & & & & \\
\hline 57 & Asio flammeus & A & & & & & & & & & & 1 & 1 & & & & & & \\
\hline & cf. Asio flammeus & A & & & & & & & & & 1 & 1 & 1 & & & & & & \\
\hline & Asio flammeus/Asio otus & & & & & & & & & & & & & & & & & & \\
\hline 58 & Aegolius funereus & $\mathrm{F}$ & & & & & & & & & & & & & & & & & \\
\hline & Strigiformes middle size & & & & & & & & & & & & & & 1 & & & & 1 \\
\hline Ap & odiformes & & & & & & & & & & & & & & & & & & \\
\hline 59 & Tachymarptis melba & $\mathrm{O}$ & & & & & & & & & & 1 & 1 & & & & & & \\
\hline Pic & iformes & & & & & & & & & & & & & & & & & & \\
\hline 60 & Dryocopus martius & $\mathrm{F}$ & & & & & & & & & & & & & & & & & \\
\hline 61 & Dendrocopos major & $\mathrm{F}$ & & & & 1 & 1 & & & & & & & & & & & & \\
\hline Pas & sseriformes & & & & & & & & & & & & & & & & & & \\
\hline 62 & Alauda arvensis & $\mathrm{O}$ & 1 & & 1 & & & & & & & 1 & 1 & & & & & & \\
\hline 63 & Lullula arborea & $E$ & & & & & & & & & & & & & & & & & \\
\hline & Alaudidae indet. & & & & & & & & & & & & & & & & & & \\
\hline 64 & Hirundo/Cecropis & $\mathrm{O}$ & 1 & 1 & 2 & 2 & 1 & & & & & 1 & 1 & & & & & 1 & 1 \\
\hline 65 & Anthus sp. & & 1 & & 1 & & & & & & & & & & & & & & \\
\hline 66 & Motacilla cf. cinerea & A & & & & & & & & & & & & & & & & & \\
\hline 67 & Cinclus cinclus & $A$ & & & & & & & & & & & & & & & & & \\
\hline 68 & Turdus viscivorus & $\mathrm{F}$ & & & & 1 & 1 & & & & & & & & & & & & \\
\hline & Turdus viscivorus/pilaris & & & & & & & & & & & & & & & & & & \\
\hline 69 & Turdus philomelos & $\mathrm{F}$ & & & & & & & & 1 & & 1 & 1 & & & & & & \\
\hline 70 & Turdus iliacus & $\mathrm{F}$ & & & & & & & & & & & & & & & & & \\
\hline 71 & Turdus pilaris & $E$ & & & & & & & & & & & & & & & & & \\
\hline 72 & Turdus merula & $\mathrm{F}$ & & & & & & & & & & & & & & & & & \\
\hline & Turdus sp. & & & & & & & & & & & 2 & & & 1 & 1 & & & \\
\hline 73 & cf. Luscinia sp. & $E$ & & & & & & & & & & & & & & & & & \\
\hline 74 & cf. Erithacus rubecula & $\mathrm{F}$ & & & & & & & & & & & & & & & & & \\
\hline 75 & Phoenicurus phoenicurus & $\mathrm{F}$ & & & & & & & & & & & & & & & & & \\
\hline & Turdidae (small) indet. & & & & & 1 & 1 & & & & & 1 & 1 & & & & & & \\
\hline 76 & Acrocephalus arundinaceus & A & & & & & & & & & & & & & & & & 2 & 2 \\
\hline & cf. Acrocephalus arundinaceus & A & & & & & & & & & & 1 & 1 & & & & & & \\
\hline
\end{tabular}




\begin{tabular}{|c|c|c|c|c|c|c|c|c|c|c|c|c|c|c|c|c|c|c|c|c|}
\hline \multirow[b]{3}{*}{ 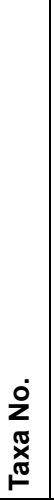 } & \multirow{3}{*}{ Taxon } & \multirow[b]{3}{*}{$\begin{array}{l}\frac{\pi}{\pi} \\
\frac{\pi}{2} \\
\frac{\pi}{\pi} \\
\text { I }\end{array}$} & \multicolumn{4}{|c|}{ 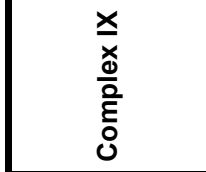 } & \multicolumn{2}{|c|}{ 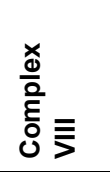 } & \multicolumn{2}{|c|}{ 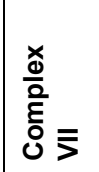 } & \multicolumn{4}{|c|}{ 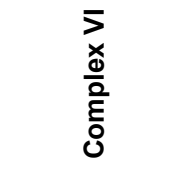 } & \multicolumn{6}{|c|}{ 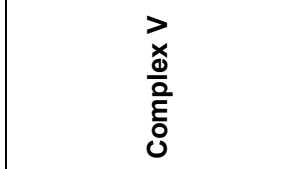 } \\
\hline & & & \multicolumn{3}{|c|}{$\frac{0}{\mathbf{n}}$} & \multirow{2}{*}{\begin{tabular}{|l}
$\frac{\sum}{\Sigma}$ \\
$\frac{\sigma}{\vdots}$ \\
$\stackrel{\infty}{-}$
\end{tabular}} & \multirow{2}{*}{$\begin{array}{l}\frac{0}{\mathbf{n}} \\
\stackrel{n}{n}\end{array}$} & \multirow{2}{*}{ 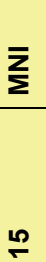 } & \multirow{2}{*}{\begin{tabular}{|l}
$\frac{0}{\text { OD }}$ \\
$\mathbf{z}$ \\
\end{tabular}} & \multirow{2}{*}{\begin{tabular}{|l}
$\mathbf{z}$ \\
$\mathbf{\Sigma}$
\end{tabular}} & \multicolumn{3}{|c|}{$\frac{\hat{0}}{\mathbf{z}}$} & \multirow{2}{*}{ 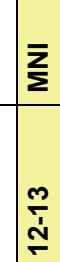 } & \multicolumn{5}{|c|}{$\frac{\hat{\infty}}{\mathbf{2}}$} & \multirow{2}{*}{\begin{tabular}{|l}
$\overline{\mathbf{Z}}$ \\
$\overline{\mathbf{\Sigma}}$ \\
$\bar{\infty}$
\end{tabular}} \\
\hline & & & $\stackrel{9}{2}$ & $\stackrel{\infty}{\sim}$ & $\frac{\sigma}{\infty}$ & & & & & & $\stackrel{m}{\sim}$ & 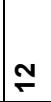 & مै & & $\mp$ & 우 & 0 & $\infty$ & $\sigma_{\infty}$ & \\
\hline 777 & cf. Oenanthe oenanthe & 0 & & & & & & & & & & & & & & & & & & \\
\hline 78 & cf. Sylvia sp. & & & & & & & & & & & & & & & & & & & \\
\hline 79 & Parus major & $\mathrm{F}$ & & & & & & & & & & & & & & & & & & \\
\hline 80 & Parus (Poecile) cf. palustris & $\mathrm{F}$ & & & & & & & & & & & & & & & & & & \\
\hline 81 & cf. Sitta sp. & & 1 & & & 1 & & & & & & & & & & & & & & \\
\hline \begin{tabular}{|l|}
82 \\
\end{tabular} & Garrulus glandarius & $\mathrm{F}$ & & & & & & & & & & & & & & & & & & \\
\hline \begin{tabular}{|l|l|}
83 \\
\end{tabular} & Pica pica & $\mathrm{E}$ & 1 & 1 & & 2 & & & & & & & & & & & & & & \\
\hline \begin{tabular}{|l|}
84 \\
\end{tabular} & Nucifraga caryocatactes & $\mathrm{F}$ & & & & & 1 & 1 & & & & & & & & & & & & \\
\hline \multirow[t]{2}{*}{85} & Pyrrhocorax graculus & $\mathrm{O}$ & & & & & & & & & & & & & & & & & & \\
\hline & Pyrrhocorax sp. & $\mathrm{O}$ & & & & & & & & & & 1 & & 1 & & & & & & \\
\hline \multirow[t]{3}{*}{86} & Corvus monedula & $\mathrm{E}$ & 2 & & & 1 & 2 & 1 & 1 & 1 & & 1 & 1 & 1 & & & 1 & & & 1 \\
\hline & Corvus monedula/Pyrrhocorax & & & & & & 9 & & & & & & & & & & & & & \\
\hline & Corvidae (small) indet. & & 1 & & & & 10 & & & & & & & & & 1 & 1 & & & \\
\hline \begin{tabular}{|l|}
87 \\
\end{tabular} & Corvus (size corone/frugilegus) & $\mathrm{E}$ & 1 & & & 1 & & & & & & & & & & & & & & \\
\hline 88 & Corvus corax & $\mathrm{F}$ & 1 & 1 & & 2 & & & & & & & 1 & 1 & & & 2 & & & 1 \\
\hline \begin{tabular}{|l|}
89 \\
\end{tabular} & Sturnus vulgaris & $E$ & & 1 & & 1 & & & & & & & & & & & & & & \\
\hline 90 & cf. Montifringilla nivalis & $\mathrm{O}$ & & & & & & & & & & & & & & & & & & \\
\hline 91 & Carduelis chloris & $\mathrm{F}$ & & & & & & & & & & & 1 & 1 & & & & & & \\
\hline 92 & Carduelis flammea & $\mathrm{T}$ & & & & & & & & & & & & & & & & & & \\
\hline 93 & Loxia cf. curvirostra & $\mathrm{F}$ & & & & & & & & & & & 2 & 1 & & & 1 & & & 1 \\
\hline \multirow[t]{2}{*}{94} & Loxia pytyopsittacus & $\mathrm{F}$ & & & & & 1 & 1 & & & & & & & & & & & & \\
\hline & Loxia sp. & $\mathrm{F}$ & & & & & 1 & & & & & & & & & & & & & \\
\hline \begin{tabular}{|l|}
95 \\
\end{tabular} & Pinicola enucleator & $\mathrm{F}$ & & & & & & & & & & & & & & & & & & \\
\hline \multirow[t]{5}{*}{96} & Cocc.coccothraustes & $\mathrm{F}$ & & & & & & & & & & & & & & & & & & \\
\hline & cf. Cocc.coccothraustes & $\mathrm{F}$ & & & & & & & & & 1 & & & 1 & & & & & & \\
\hline & Fringillidae size Chloris & & 1 & & & 1 & & & & & & & & & & & & & & \\
\hline & cf. Fringillidae indet. & & & & & & & & & & & 1 & & 1 & & & & & & \\
\hline & Passeriformes indet & & 3 & & & & & & & & 1 & & & & & & & & & \\
\hline & & & & & & & & & & & & & & & & & & & & \\
\hline & Aves indet & & 7 & 3 & & & 33 & & & & & 6 & 2 & & & 9 & & & & \\
\hline & TOTAL & & 54 & 23 & 5 & 32 & 101 & 19 & 8 & 4 & 8 & 20 & 76 & 36 & 2 & 54 & 24 & 2 & 19 & 29 \\
\hline
\end{tabular}


TABLE 2b. Bird remains identified in layers 7-1 (fauna complexes IV-I) in Biśnik Cave. Categories of habitat (see Material and Methods): A, amphibious; E, ecotone; F, forest; O, open; T, tundra. To exclude double counting of remains, before computing the minimum number of individuals (MNI) for mixed complexes it was always checked whether the remains from mixed sediments may have belonged to birds from layers with well-defined stratigraphy. Total refers to data from both parts of Table 2 ( $a$ and $b$ ).

\begin{tabular}{|c|c|c|c|c|c|c|c|c|c|c|c|c|c|c|c|c|c|c|c|c|}
\hline \multirow[b]{3}{*}{ 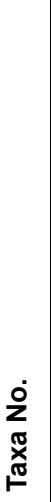 } & \multirow{3}{*}{ Taxon } & \multirow[b]{3}{*}{$\begin{array}{l}\frac{t}{\pi} \\
\frac{\pi}{0} \\
\frac{0}{10} \\
\frac{\pi}{1}\end{array}$} & \multicolumn{4}{|c|}{$\begin{array}{l}\geq \\
x \\
\frac{x}{0} \\
\overline{0} \\
0\end{array}$} & \multicolumn{4}{|c|}{$\begin{array}{l} \\
x \\
\frac{0}{0} \\
\frac{0}{\varepsilon} \\
0 \\
0\end{array}$} & \multicolumn{2}{|c|}{$\begin{array}{l}\overline{\bar{x}} \\
\frac{0}{0} \\
\frac{0}{\varepsilon} \\
0\end{array}$} & \multicolumn{2}{|c|}{ 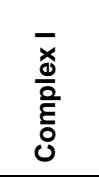 } & \multicolumn{4}{|c|}{ 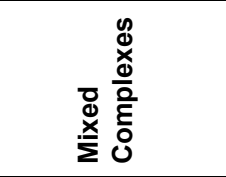 } & \multicolumn{2}{|c|}{$\begin{array}{l}\bar{\pi} \\
\text { 0 }\end{array}$} \\
\hline & & & \multicolumn{3}{|c|}{$\frac{\hat{\omega}}{2}$} & \multirow{2}{*}{\begin{tabular}{|l}
$\mathbf{\Sigma}$ \\
$\mathbf{\Sigma}$ \\
$\hat{\mathbf{b}}$
\end{tabular}} & \multicolumn{3}{|c|}{$\frac{\hat{\omega}}{2}$} & \multirow{2}{*}{\begin{tabular}{|c|}
$\bar{z}$ \\
$\mathbf{\Sigma}$ \\
$\dot{m}$
\end{tabular}} & \multirow{2}{*}{$\begin{array}{l}\frac{0}{\boldsymbol{\omega}} \\
\mathbf{2}\end{array}$} & \multirow{2}{*}{$\begin{array}{l}\bar{\Sigma} \\
\mathbf{\Sigma} \\
\mathbf{N}\end{array}$} & \multirow{2}{*}{$\begin{array}{l}\frac{0}{\mathbf{\infty}} \\
- \\
-\end{array}$} & \multirow{2}{*}{\begin{tabular}{|l}
$\mathbf{z}$ \\
\end{tabular}} & \multicolumn{3}{|c|}{$\frac{\text { ô }}{z}$} & \multirow[b]{2}{*}{$\bar{\Sigma}$} & \multirow[b]{2}{*}{$\frac{0}{2}$} & \\
\hline & & & $\sim$ & 0 & 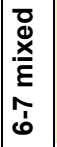 & & $\theta$ & $m$ & 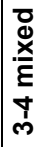 & & & & & & 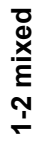 & 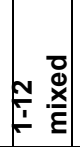 & $\sim$ & & & $\overline{\mathbf{z}}$ \\
\hline Poc & licipediformes & & & & & & & & & & & & & & & & & & & \\
\hline 1 & cf. Podiceps cristatus/grisegena & A & & & & & & & & & & & & & & & 1 & 1 & 1 & 1 \\
\hline Ans & eriformes & & & & & & & & & & & & & & & & & & & \\
\hline 2 & Anser/Branta & A & & & & & & & & & & & 1 & 1 & & & 2 & & 4 & 2 \\
\hline 3 & Branta bernicla & $\mathrm{T}$ & & & & & & & & & & & & & & & 3 & 1 & 3 & 1 \\
\hline & cf. Branta bernicla & $\mathrm{T}$ & & & 1 & 1 & & & & & & & & & & 1 & 1 & & 3 & 1 \\
\hline 4 & Tadorna tadorna & $A$ & & & & & & & & & & & & & & & 1 & 1 & 1 & 1 \\
\hline 5 & cf. Anas strepera & $A$ & & & 1 & 1 & & & & & & & & & & 2 & 1 & & 4 & 1 \\
\hline 6 & Anas crecca & $A$ & & & & & & & & & & & & & & & 2 & 2 & 2 & 2 \\
\hline 7 & Anas platyrhynchos & $A$ & & & & & & & & & & & 2 & 1 & 1 & 2 & 9 & 1 & 15 & 3 \\
\hline & cf. Anas platyrhynchos & $A$ & & & & & & & & & 1 & 1 & & & & & 1 & & 4 & 3 \\
\hline 8 & Anas querquedula & $A$ & & & 1 & 1 & & & & & 1 & 1 & & & & & 4 & & 7 & 3 \\
\hline & Anas querquedula/crecca & $A$ & & & 1 & 1 & & & & & 2 & 1 & & & & 3 & 6 & & 18 & 7 \\
\hline 9 & Anas clypeata & $A$ & & & & & & & & & & & & & 1 & & 2 & 3 & 3 & 3 \\
\hline & Anas cf. clypeata & $A$ & & & & & & & & & 1 & 1 & & & & & 1 & & 2 & 1 \\
\hline & Anas sp. & $A$ & & & 2 & 1 & & & & & & & & & & 2 & 1 & & 5 & 1 \\
\hline 10 & Aythya fuligula & $A$ & & & & & & & & & & & & & 1 & & & & 2 & 1 \\
\hline 11 & Melanitta nigra & $A$ & & & & & & & & & & & & & & & 1 & 1 & 1 & 1 \\
\hline 12 & Melanitta fusca & $A$ & & & & & & & & & & & & & & & 1 & 1 & 1 & 1 \\
\hline 13 & Bucephala clangula & $A$ & & & & & & & & & 1 & 1 & & & & & 1 & & 2 & 1 \\
\hline & cf. Bucephala clangula & $A$ & & & & & & & & & & & & & & 1 & 2 & 2 & 3 & 2 \\
\hline 14 & Mergellus albellus & $A$ & & & & & & & & & & & & & & 1 & 3 & & 6 & 2 \\
\hline 15 & cf. Mergus merganser & $A$ & & & & & & & & & & & & & & & 1 & 1 & 1 & 1 \\
\hline & Anatinae indet. & $A$ & & & & & & & & & & & & & & & 5 & & 7 & 0 \\
\hline Fal & coniformes & & & & & & & & & & & & & & & & & & & \\
\hline 16 & Circus sp. & 0 & & & & & & & & & & & & & & & 1 & 1 & 1 & 1 \\
\hline 17 & Accipiter nisus & $E$ & & & & & & & & & & & 1 & 1 & & & & & 1 & 1 \\
\hline & cf. Accipiter nisus & $E$ & & & & & & & & & & & & & & & & & 1 & 1 \\
\hline 18 & Accipiter gentilis & $E$ & & & & & & & & & & & & & 1 & & 1 & 1 & 2 & 1 \\
\hline 19 & Buteo buteo & $E$ & & & & & & & & & & & & & & 1 & 1 & 1 & 2 & 1 \\
\hline & Buteo buteo/lagopus & $E$ & & & & & & & & & & & & & 1 & & 6 & & 7 & 0 \\
\hline 20 & cf. Aquila heliaca & $E$ & & & & & & & & & & & & & & 1 & & 1 & 1 & 1 \\
\hline & Aquila sp. & $E$ & & & & & & & & & & & & & & & 1 & & 1 & 0 \\
\hline 21 & Falco tinnunculus & $E$ & 1 & & 2 & 2 & & & 1 & 1 & 2 & 1 & 6 & 2 & 4 & 5 & 25 & & 54 & 12 \\
\hline
\end{tabular}




\begin{tabular}{|c|c|c|c|c|c|c|c|c|c|c|c|c|c|c|c|c|c|c|c|c|}
\hline \multirow[b]{3}{*}{ 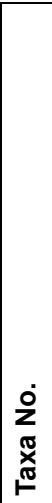 } & \multirow{3}{*}{ Taxon } & \multirow[b]{3}{*}{ 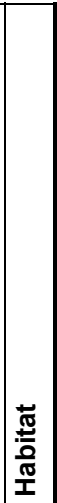 } & \multicolumn{4}{|c|}{$\begin{array}{l}\geq \\
x \\
\frac{0}{0} \\
\frac{0}{E} \\
0 \\
0\end{array}$} & \multicolumn{4}{|c|}{ 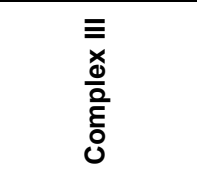 } & \multicolumn{2}{|c|}{ 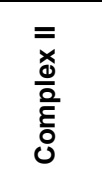 } & \multicolumn{2}{|c|}{$\begin{array}{l}\bar{x} \\
\frac{0}{0} \\
\overline{0} \\
0\end{array}$} & \multicolumn{4}{|c|}{ 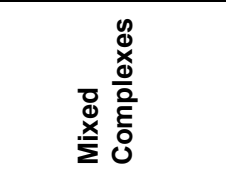 } & \multicolumn{2}{|c|}{$\begin{array}{l}\overline{\mathbb{Z}} \\
\stackrel{0}{0}\end{array}$} \\
\hline & & & \multicolumn{3}{|c|}{$\frac{\hat{\omega}}{2}$} & \multirow{2}{*}{\begin{tabular}{|l}
$\overline{\mathbf{z}}$ \\
$\hat{\mathbf{z}}$
\end{tabular}} & \multicolumn{3}{|c|}{$\frac{\hat{0}}{2}$} & \multirow{2}{*}{\begin{tabular}{|c|}
$\bar{\Sigma}$ \\
$\underset{\text { z }}{\mathbf{\Sigma}}$
\end{tabular}} & \multirow{2}{*}{$\begin{array}{l}\frac{0}{\mathbf{n}} \\
\\
\text { N }\end{array}$} & \multirow{2}{*}{$\begin{array}{c}\bar{\Sigma} \\
\text { N } \\
\end{array}$} & \multirow{2}{*}{$\begin{array}{l}\frac{0}{\mathbf{n}} \\
-\end{array}$} & $\overline{\mathbf{z}}$ & & $\frac{\hat{\Phi}}{z}$ & & & & \\
\hline & & & $\Lambda$ & 0 & 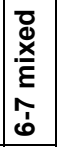 & & $\theta$ & $m$ & 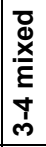 & & & & & - & 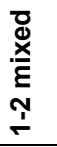 & 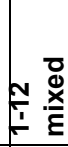 & $\sim$ & $\overline{\mathbf{z}}$ & $\frac{0}{2}$ & $\overline{\mathbf{z}}$ \\
\hline 22 & Falco tinnunculus atavus & & & & & & & & & & & & & & & & 2 & 1 & $\overline{2}$ & $\overline{1}$ \\
\hline & Falco cf. tinnunculus & $E$ & & & & & & & & & & & & & & 2 & 2 & & 6 & 2 \\
\hline 23 & Falco cf. subbuteo & $E$ & & & & & & & & & & & 1 & 1 & & & & & 1 & 1 \\
\hline 24 & Falco peregrinus & $\mathrm{F}$ & & & & & & & & & & & & & & & 1 & 1 & 1 & 1 \\
\hline 25 & Falco cf. rusticolus & $\mathrm{T}$ & & & & & & & & & & & & & & & 1 & & 3 & 1 \\
\hline & Falco sp. & & & & 5 & 1 & & & & & & & 1 & & 1 & 4 & 12 & & 22 & 1 \\
\hline & Falconiformes middle size & & & & & & & & & & & & & & 2 & & & & 2 & 0 \\
\hline & Falconiformes small size & & & & & & & & & & & & & & 2 & & & & 2 & 0 \\
\hline Gall & liformes & & & & & & & & & & & & & & & & & & & \\
\hline 26 & Lagopus lagopus & $\mathrm{T}$ & 1 & 1 & 11 & 3 & 2 & 3 & & 2 & 20 & 3 & 7 & 1 & 12 & 13 & 59 & & 200 & 23 \\
\hline 27 & Lagopus muta & $T$ & & & 1 & 1 & 2 & & & 1 & 6 & 1 & 1 & 1 & 3 & & 10 & & 30 & 9 \\
\hline & Lagopus sp. & $\mathrm{T}$ & & & 1 & & & 1 & & & 4 & & 4 & & 2 & 7 & 34 & & 88 & 0 \\
\hline 28 & Tetrao tetrix & $\mathrm{F}$ & & & 6 & 1 & & 1 & & 1 & 23 & 4 & 9 & 2 & 18 & 14 & 80 & & 213 & 19 \\
\hline 29 & Tetrao urogallus & $\mathrm{F}$ & & & 1 & 1 & & & & & & & 4 & 1 & 2 & 3 & 6 & & 28 & 6 \\
\hline & Tetrao sp. & $F$ & & & & & & & & & & & & & & & 1 & & 3 & 0 \\
\hline & Tetrao/Lagopus & & & & & & & & & & 1 & & 2 & & & & 1 & & 10 & 0 \\
\hline 30 & Bonasa bonasia & $\mathrm{F}$ & & & & & & & & & & & 6 & 1 & 1 & & & & 8 & 2 \\
\hline 31 & Perdix perdix & 0 & & & & & & & & & & & & & & 1 & & & 2 & 1 \\
\hline \begin{tabular}{|l|}
32 \\
\end{tabular} & Coturnix coturnix & 0 & & & & & & & & & & & & & & & 1 & & 2 & 1 \\
\hline \begin{tabular}{|l|}
33 \\
\end{tabular} & Gallus gallus & & & & & & & & & & 2 & 1 & 100 & 14 & 33 & & 38 & & 173 & 15 \\
\hline & Galliformes indet & & & & 1 & & & & & & 1 & & 2 & & 3 & & 5 & & 15 & 0 \\
\hline Gru & iformes & & & & & & & & & & & & & & & & & & & \\
\hline 34 & Rallus aquaticus & A & & & & & & & & & & & & & 1 & & 3 & 1 & 4 & 1 \\
\hline 35 & Porzana porzana & $A$ & & & 1 & 1 & & & & & & & & & & & 2 & & 3 & 1 \\
\hline 36 & Crex crex & A & & & & & & & & & 2 & 2 & 1 & 1 & & & 4 & & 9 & 5 \\
\hline Cha & radriiformes & & & & & & & & & & & & & & & & & & & \\
\hline 37 & cf. Charadrius morinellus & $\mathrm{T}$ & & & & & & & & & & & & & & & & & 1 & 1 \\
\hline 38 & Pluvialis apricaria & $\mathrm{T}$ & & & & & & & & & & & 1 & 1 & & & 2 & & 5 & 3 \\
\hline 39 & Pluvialis squatarola & $\mathrm{T}$ & & & 1 & 1 & & & & & & & & & & & & & 1 & 1 \\
\hline 40 & Vanellus vanellus & $A$ & & & & & & & & & & & & & & & 2 & & 4 & 2 \\
\hline & cf. Vanellus vanellus & $A$ & & & & & & & & & & & & & & & & & 1 & 1 \\
\hline 41 & Philomachus pugnax & $A$ & & & 1 & 1 & & & 1 & 1 & 1 & 1 & 2 & 1 & 1 & & 3 & & 10 & 5 \\
\hline 42 & Gallinago media & $A$ & & & & & & & & & 2 & 1 & 1 & 1 & 2 & & 5 & 3 & 10 & 5 \\
\hline & cf. Gallinago media & $A$ & & & & & & & & & 1 & 1 & & & 1 & 1 & 1 & & 4 & 1 \\
\hline 43 & Scolopax rusticola & $\mathrm{F}$ & & & & & & & & & 1 & 1 & & & & & 1 & & 5 & 3 \\
\hline 44 & cf. Limosa limosa & $A$ & & & & & & & & & 1 & 1 & & & & & & & 1 & 1 \\
\hline 45 & Tringa totanus/erythropus & $A$ & & & & & & & & & & & & & & & 1 & 1 & 1 & 1 \\
\hline 46 & Tringa ochropus & $A$ & & & & & & & & & & & & & & & & & 1 & 1 \\
\hline 47 & Arenaria interpres & $\mathrm{T}$ & & & & & 1 & & & 1 & & & & & & & & & 1 & 1 \\
\hline \begin{tabular}{|l|}
48 \\
\end{tabular} & Stercorarius sp. & $A$ & & & & & & & & & & & 1 & 1 & & & 1 & & 2 & 1 \\
\hline 49 & Rissa tridactyla & $A$ & & & & & & & & & & & 1 & 1 & & & & & 1 & 1 \\
\hline & Charadriiformes indet. & $A$ & & & & & & & & & 2 & & & & & 1 & 2 & & 8 & 0 \\
\hline
\end{tabular}




\begin{tabular}{|c|c|c|c|c|c|c|c|c|c|c|c|c|c|c|c|c|c|c|c|c|}
\hline \multirow[b]{3}{*}{ 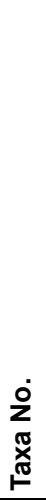 } & \multirow{3}{*}{ Taxon } & \multirow[b]{3}{*}{$\begin{array}{l}\frac{\pi}{\pi} \\
\frac{\pi}{0} \\
\frac{0}{\pi} \\
\frac{\pi}{1}\end{array}$} & \multicolumn{4}{|c|}{$\begin{array}{l}\geq \\
\frac{x}{0} \\
\frac{0}{\varrho} \\
0 \\
0\end{array}$} & \multicolumn{4}{|c|}{$\begin{array}{l}\equiv \\
\bar{x} \\
\frac{0}{0} \\
\frac{\partial}{0}\end{array}$} & \multicolumn{2}{|c|}{$\begin{array}{l}= \\
\frac{x}{0} \\
\frac{0}{\varepsilon} \\
0\end{array}$} & \multicolumn{2}{|c|}{$\begin{array}{l}\bar{x} \\
\frac{\alpha}{0} \\
\frac{0}{\varepsilon} \\
\text { ல }\end{array}$} & \multicolumn{4}{|c|}{ 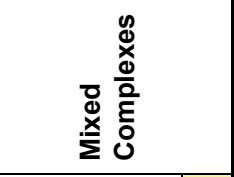 } & \multicolumn{2}{|c|}{$\begin{array}{l}\bar{\Xi} \\
\stackrel{0}{\circ}\end{array}$} \\
\hline & & & \multicolumn{3}{|c|}{$\frac{n}{\mathbf{D}}$} & \multirow{2}{*}{\begin{tabular}{|c}
$\bar{\Sigma}$ \\
$\mathbf{\Sigma}$ \\
$\hat{\vdots}$
\end{tabular}} & \multicolumn{3}{|c|}{$\frac{0}{\frac{0}{2}}$} & \multirow{2}{*}{\begin{tabular}{|c}
$\bar{\Sigma}$ \\
$\mathbf{\Sigma}$ \\
$\dot{m}$
\end{tabular}} & \multirow{2}{*}{$\begin{array}{l}\frac{0}{z} \\
\text { N }\end{array}$} & \multirow{2}{*}{$\begin{array}{l}\bar{\Sigma} \\
\mathbf{\Sigma} \\
\mathbf{N}\end{array}$} & \multirow{2}{*}{$\begin{array}{l}\frac{0}{\mathbf{s}} \\
-\end{array}$} & $\overline{\mathbf{z}}$ & & $\frac{0}{2}$ & & & & \\
\hline & & & $\Lambda$ & 0 & 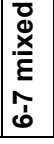 & & $\theta$ & $m$ & 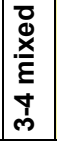 & & & & & - & 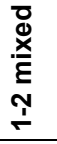 & 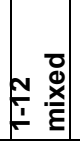 & $\sim$ & $\overline{\mathbf{z}}$ & $\frac{0}{\text { क }}$ & $\bar{\Sigma}$ \\
\hline & umbiformes & & & & & & & & & & & & & & & & & & & \\
\hline 50 & Columba palumbus & $\mathrm{F}$ & & & & & & & & & 1 & 1 & 1 & 1 & & & & & 3 & 3 \\
\hline & uliformes & & & & & & & & & & & & & & & & & & & \\
\hline 51 & Cuculus canorus & $E$ & & & & & & & & & & & & & & & 1 & 1 & 1 & 1 \\
\hline & giformes & & & & & & & & & & & & & & & & & & & \\
\hline 52 & Bubo bubo & $F$ & & & & & & & & & & & & & & & 1 & 1 & 1 & 1 \\
\hline 53 & Strix aluco & $E$ & & & & & & & & & 7 & 2 & 4 & 2 & 7 & & 4 & & 23 & 5 \\
\hline 54 & Strix uralensis & $F$ & & & & & & & & & & & & & & & & & 2 & 2 \\
\hline 55 & cf. Strix nebulosa & $\mathrm{F}$ & & & & & & & & & & & & & 1 & & & 1 & 1 & 1 \\
\hline & cf. Strix sp. & & & & & & & & & & & & & & & & & & 1 & 1 \\
\hline 56 & Surnia ulula & $\mathrm{F}$ & & & & & 1 & & & 1 & & & 1 & 1 & & & 1 & & 5 & 3 \\
\hline 57 & Asio flammeus & A & & & & & & & & & 2 & 1 & 1 & 1 & 1 & & 1 & & 6 & 3 \\
\hline & cf. Asio flammeus & A & & & & & & & & & & & & & 2 & & 2 & & 6 & 1 \\
\hline & Asio flammeus/Asio otus & & & & & & & & & & & & & & 1 & & & & 1 & 0 \\
\hline 58 & Aegolius funereus & $\mathrm{F}$ & & & & & & & & & & & 1 & 1 & & 1 & & & 2 & 1 \\
\hline & Strigiformes middle size & & & & & & & & & & & & & & 2 & & 1 & & 4 & 1 \\
\hline & diformes & & & & & & & & & & & & & & & & & & & \\
\hline 59 & Tachymarptis melba & $\mathrm{O}$ & & & 1 & 1 & & & & & & & & & & 2 & & & 4 & 2 \\
\hline & formes & & & & & & & & & & & & & & & & & & & \\
\hline 60 & Dryocopus martius & $\mathrm{F}$ & & & & & & & & & 1 & 1 & & & & & & & 1 & 1 \\
\hline 61 & Dendrocopos major & $\mathrm{F}$ & & & & & & & & & & & & & & & & & 1 & 1 \\
\hline & seriformes & & & & & & & & & & & & & & & & & & & \\
\hline 62 & Alauda arvensis & $\mathrm{O}$ & & & 1 & 1 & & & & & & & 2 & 1 & & & 3 & & 8 & 4 \\
\hline 63 & Lullula arborea & $E$ & & & & & & & & & 1 & 1 & & & & & & & 1 & 1 \\
\hline & Alaudidae indet. & & & & & & & & & & & & & & & & 1 & & 1 & 0 \\
\hline 64 & Hirundo/Cecropis & $\mathrm{O}$ & & & & & & & & & 3 & 2 & & & 1 & 1 & 2 & & 13 & 7 \\
\hline 65 & Anthus sp. & & & & & & & & & & & & & & & & & & 1 & 1 \\
\hline 66 & Motacilla cf. cinerea & $A$ & & & & & & & & & & & 1 & 1 & & & & & 1 & 1 \\
\hline 67 & Cinclus cinclus & A & & & 1 & 1 & & & & & & & & & & & & & 1 & 1 \\
\hline 68 & Turdus viscivorus & $F$ & & & 1 & 1 & & & & & 1 & 1 & 1 & 1 & 3 & 2 & 2 & & 11 & 4 \\
\hline & Turdus viscivorus/pilaris & & & & $3 \mid$ & 2 & & & & & 1 & & 2 & 1 & 1 & & 1 & & 8 & 3 \\
\hline 69 & Turdus philomelos & $\mathrm{F}$ & & & 1 & 1 & & & & & 1 & 1 & 2 & 1 & & 2 & 5 & & 13 & 4 \\
\hline 70 & Turdus iliacus & $\mathrm{F}$ & & & & & & & & & & & & & & & 1 & 1 & 1 & 1 \\
\hline 71 & Turdus pilaris & $E$ & & & & & & & & & & & 5 & 2 & 2 & 1 & 6 & & 14 & 2 \\
\hline 72 & Turdus merula & $\mathrm{F}$ & & & & & & & & & 2 & 1 & 2 & 1 & & & & & 4 & 2 \\
\hline & Turdus sp. & & & & & & & & & & 1 & & 4 & & 5 & 2 & 16 & & 32 & 0 \\
\hline 73 & cf. Luscinia sp. & $E$ & & & & & & & & & & & & & & 1 & & 1 & 1 & 1 \\
\hline 74 & cf. Erithacus rubecula & $\mathrm{F}$ & & & 1 & 1 & & & & & & & & & & & & & 1 & 1 \\
\hline 75 & Phoenicurus phoenicurus & $\mathrm{F}$ & & & & & & & & & & & & & 1 & & & 1 & 1 & 1 \\
\hline & Turdidae (small) indet. & & & & & & & & 3 & 2 & & & & & & & & & 5 & 4 \\
\hline 76 & Acrocephalus arundinaceus & A & & & & & & & & & & & & & & & & & 2 & 2 \\
\hline & cf. Acrocephalus arundinaceus & A & & & & & & & & & & & & & & & & & 1 & 1 \\
\hline
\end{tabular}




\begin{tabular}{|c|c|c|c|c|c|c|c|c|c|c|c|c|c|c|c|c|c|c|c|c|}
\hline \multirow[b]{3}{*}{ 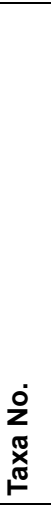 } & \multirow{3}{*}{ Taxon } & \multirow[b]{3}{*}{ 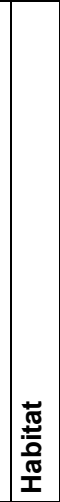 } & \multicolumn{4}{|c|}{$\begin{array}{l}\geq \\
x \\
\frac{0}{0} \\
\text { है } \\
0\end{array}$} & \multicolumn{4}{|c|}{ 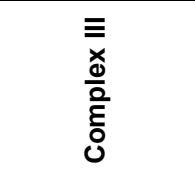 } & \multicolumn{2}{|c|}{ 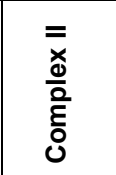 } & \multicolumn{2}{|c|}{ 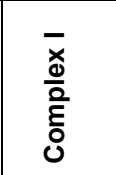 } & \multicolumn{4}{|c|}{ 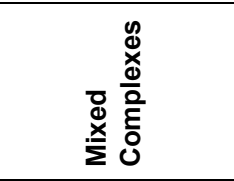 } & \multicolumn{2}{|l|}{ 蛋 } \\
\hline & & & \multicolumn{3}{|c|}{$\frac{0}{2}$} & \multirow{2}{*}{\begin{tabular}{|l|}
$\mathbf{z}$ \\
$\mathbf{\Sigma}$ \\
$\hat{o}$
\end{tabular}} & \multicolumn{3}{|c|}{$\frac{0}{2}$} & \multirow{2}{*}{\begin{tabular}{|c|}
$\bar{\Sigma}$ \\
ষ
\end{tabular}} & \multirow{2}{*}{$\begin{array}{l}\frac{0}{\mathbf{w}} \\
\mathrm{N}\end{array}$} & \multirow{2}{*}{$\begin{array}{l}\bar{\Sigma} \\
\mathbf{N} \\
\end{array}$} & \multirow{2}{*}{$\begin{array}{l}\frac{0}{\mathbf{n}} \\
- \\
-\end{array}$} & \multirow{2}{*}{$\begin{array}{l}\bar{\Sigma} \\
\mathbf{\Sigma} \\
\\
\\
-\end{array}$} & \multicolumn{3}{|c|}{$\frac{0}{2}$} & \multirow[b]{2}{*}{$\bar{\Sigma}$} & \multirow[b]{2}{*}{$\frac{\text { के }}{z}$} & \multirow[b]{2}{*}{$\bar{\Sigma}$} \\
\hline & & & $\Lambda$ & 0 & 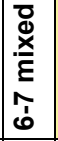 & & $\theta$ & $m$ & 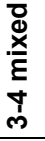 & & & & & & 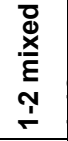 & 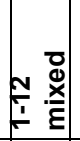 & $\sim$ & & & \\
\hline 77 & cf. Oenanthe oenanthe & 0 & & & & & & & & & 1 & 1 & & & & & & & 1 & $\overline{11}$ \\
\hline 78 & cf. Sylvia sp. & & & & & & & & & & 1 & 1 & & & & & & & 1 & 1 \\
\hline 79 & Parus major & $\mathrm{F}$ & & & & & & & & & & & 1 & 1 & & & & & 1 & 1 \\
\hline 80 & Parus (Poecile) cf. palustris & $\mathrm{F}$ & & & & & & & & & & & & & & & 2 & 2 & 2 & 2 \\
\hline 81 & cf. Sitta sp. & & & & & & & & & & & & & & & & & & 1 & 1 \\
\hline 82 & Garrulus glandarius & $\mathrm{F}$ & & & 1 & 1 & & & & & & & 7 & 1 & & 2 & 18 & & 28 & 2 \\
\hline 83 & Pica pica & $\mathrm{E}$ & & & & & & & & & & & & & 1 & & 1 & & 4 & 2 \\
\hline 84 & Nucifraga caryocatactes & $\mathrm{F}$ & & & & & & & & & & & & & & & 2 & & 3 & 1 \\
\hline \multirow[t]{2}{*}{85} & Pyrrhocorax graculus & $\mathrm{O}$ & & & & & & & & & & & & & & & 1 & 1 & 1 & 1 \\
\hline & Pyrrhocorax sp. & $\mathrm{O}$ & & & & & & & & & & & & & & & & & 1 & 1 \\
\hline 86 & Corvus monedula & $E$ & & & 7 & 1 & & & & & 4 & 1 & 2 & 1 & 1 & 2 & 26 & & 50 & 8 \\
\hline & Corvus monedula/Pyrrhocorax & & & & 1 & & & & & & & & & & & & & & 10 & 0 \\
\hline & Corvidae (small) indet. & & & & 6 & & 2 & & & & 5 & & 5 & & 3 & 6 & 27 & & 67 & 0 \\
\hline 87 & Corvus (size corone/frugilegus) & $\mathrm{E}$ & & & & & & & & & & & & & & & & & 1 & 1 \\
\hline 88 & Corvus corax & $\mathrm{F}$ & & & & & & & & & 4 & 2 & & & & & 2 & & 11 & 6 \\
\hline 89 & Sturnus vulgaris & $\mathrm{E}$ & & & 3 & 2 & & & & & & & & & 2 & 2 & 5 & & 13 & 3 \\
\hline 90 & cf. Montifringilla nivalis & $\mathrm{O}$ & & & & & & & & & 1 & 1 & & & & 1 & 2 & & 4 & 1 \\
\hline 91 & Carduelis chloris & $\mathrm{F}$ & & & & & & & & & & & & & & & & & 1 & 1 \\
\hline 92 & Carduelis flammea & $\mathrm{T}$ & & & & & & & & & 1 & 1 & & & & & & & 1 & 1 \\
\hline 93 & Loxia cf. curvirostra & $\mathrm{F}$ & & & & & & & & & & & & & & & & & 3 & 2 \\
\hline 94 & Loxia pytyopsittacus & $\mathrm{F}$ & & & & & & & & & & & & & & & 1 & & 2 & 1 \\
\hline & Loxia sp. & $\mathrm{F}$ & & & & & & & & & & & 1 & 1 & & 1 & & & 3 & 1 \\
\hline 95 & Pinicola enucleator & $\mathrm{F}$ & & & & & & & & & & & & & & & 1 & 1 & 1 & 1 \\
\hline 96 & Cocc.coccothraustes & $\mathrm{F}$ & & & & & & & & & & & 1 & 1 & & & 1 & & 2 & 1 \\
\hline & cf. Cocc.coccothraustes & $\mathrm{F}$ & & & & & & & & & & & & & & & & & 1 & 1 \\
\hline & Fringillidae size Chloris & & & & & & & & & & & & & & & & & & 1 & 1 \\
\hline & cf. Fringillidae indet. & & & & & & & & & & & & & & & & & & 1 & 1 \\
\hline & Passeriformes indet & & & & & & & & & & 1 & & 1 & & & & 6 & & 12 & 0 \\
\hline & & & & & & & & & & & & & & & & & & & & \\
\hline & Aves indet & & & & & & & 1 & 1 & & 4 & & 7 & & 6 & 2 & 42 & & 123 & 0 \\
\hline & TOTAL & & 2 & 1 & 64 & 29 & 8 & 6 & 6 & 10 & 118 & 40 & 206 & 51 & 133 & 93 & 549 & 35 & 1582 & 285 \\
\hline
\end{tabular}

